Rosilene de Melo Menezes

\title{
Estudo clínico, patológico e detecção do papillomavírus humano no carcinoma de células escamosas de orofaringe tratados por cirurgia
}

Tese apresentada à Faculdade de Medicina da Universidade de São Paulo para obtenção do título de Doutor em Ciências

Programa de Oncologia Orientador: Prof. Dr. Luiz Paulo Kowalski

São Paulo

2016 
Dados Internacionais de Catalogação na Publicação (CIP)

Preparada pela Biblioteca da

Faculdade de Medicina da Universidade de São Paulo

Creprodução autorizada pelo autor

Menezes, Rosilene de Melo

Estudo clínico, patológico e detecção do papillomavírus humano no carcinoma de células escamosas de orofaringe tratados por cirurgia / Rosilene de Melo Menezes. -São Paulo, 2016.

Tese(doutorado)--Faculdade de Medicina da Universidade de São Paulo.

Programa de Oncologia.

Orientador: Luiz Paulo Kowalski.

Descritores: 1.Papillomaviridae 2.Carcinoma de células escamosas 3.Orofaringe 4.Análise de sobrevida 5.Estimativa de Kaplan-Meier 6.Modelos de riscos proporcionais 7.Homens 8.Mulheres

USP/FM/DBD-258/16 
Rosilene de Melo Menezes

\section{Estudo clínico, patológico e detecção do papillomavírus humano no carcinoma de células escamosas de orofaringe tratados por cirurgia}

Tese apresentada à Faculdade de Medicina da Universidade de São Paulo para obtenção do título de Doutor em Ciências

Programa de Oncologia Orientador: Prof. Dr. Luiz Paulo Kowalski

São Paulo

2016 
Agradecimentos

Ao Prof. Dr. Luiz Paulo Kowalski, pela oportunidade de realizá-la, pela atenção e dedicação com a qual corrigiu e orientou essa tese e, com seus conhecimentos transmitidos, muito colaborou para o desenvolvimento da minha formação como pesquisadora.

À Prof. Dra. Luisa Villa pela atenção, paciência e dedicação com a qual também corrigiu e orientou essa tese e com seus conhecimentos especializados até então estranhos à minha prática clínica diária, colaborou muito para o desenvolvimento dessa tese e minha formação como pesquisadora.

Ao Prof. Dr. José Eduardo Levi, pelas considerações no exame de qualificação extremamente úteis e coerentes.

À Prof. Dra Lara Termini, pelas considerações no exame de qualificação contundentes, objetivas e precisas.

À Prof. Dra. Laura Schiero, pela paciência e considerações práticas no ensino e apresentação das técnicas de biologia molecular e avaliação precisa no exame de qualificação.

À Prof. Dra. Maria do Rosário Dias de Oliveira Latorre, do Departamento de Epidemiologia da Faculdade de Saúde Pública, da Universidade de São Paulo, pela análise estatística descritiva realizada no exame de qualificação e toda a análise estatística restante para a conclusão da tese e por sua amizade. 
À Prof. dra Barbara Mello pela realização e explicação da técnica da detecção do HPV.

Ao Prof. dr. Clovis Antonio Lopes Pinto pela análise das lâminas da Anatomia Patológica.

Ao técnico Sr. Severino da Silva Ferreira, pela confecção das lâminas.

Ao suporte do arquivo do AC Camargo Cancer Center, nas pessoas do Srs. Gregório, Bruno e Jonatham.

À Bibliotecária Sra. Suely Francisco e toda sua equipe.

À equipe de biblioteca da FMUSP.

A todos que contribuíram direta ou indiretamente na execução dessa tese, o meu agradecimento. 
Aos meus três meninos sempre.

Recria tua vida sempre, remove pedras e planta roseiras e faz doces. Recomeça! Cora Coralina 
Esta tese está de acordo com as seguintes normas em vigor no momento desta publicação:

Referências: adaptado de InternationalCommitteeof Medical JournalsEditors (Vancouver)

Universidade de São Paulo, Faculdade de Medicina. Divisão de Biblioteca e Documentação. Guia de apresentação de dissertações, teses e monografias. Elaborado por Anneliese Carneiro da Cunha, Maria Julia de A. L. Freddi, Maria F. Crestana, Marinalva de Souza Aragão, Suely Campos Cardoso, Valéria Vilhena. $3^{\text {a }}$ ed. São Paulo: Divisão de Biblioteca e Documentação; 2011

Abreviaturas dos títulos de periódicos de acordo com ListofJournalsIndexed in Index Medicus 


\section{Sumário}

Resumo

Abstract

1.INTRODUÇÃO 1

1.1. Epidemiologia do câncer de orofaringe 1

1.2. HPV (Papillomavirus humano) 4

1.3. Patogênese do carcinoma de orofaringe mediado por HPV 5

1.4. Diagnóstico

$\begin{array}{lr}\text { 2. OBJETIVOS } & 10\end{array}$

3. REVISÃO DE LITERATURA 11

4. MÉTODOS 30

4.1. Delineamento do estudo 30

$\begin{array}{ll}\text { 4.2. População de estudo } & 30\end{array}$

$\begin{array}{ll}\text { 4.3. Coleta de dados } & 30\end{array}$

4.4. Pesquisa do HPV 30

4.5. Variáveis do estudo 33

4.6 Análise estatística $\quad 33$

4.7. Questões éticas 34

5. RESULTADOS 35

5.1. Caracterização da amostra 35

5.2. Análise de associação com o HPV 41

5.3. Análise da sobrevida livre de doença 41

5.4. Análise da sobrevida global 43

6. DISCUSSÃO

7. CONCLUSÕES 56

8. ANEXOS

9. REFERÊNCIAS 63 


\section{Resumo}

Menezes RM. Estudoclínico e patológico e detecção do papillomavírushumano no carcinoma de célulasescamosas de orofaringetratadosporcirurgia [Tese]. SãoPaulo: Faculdade de Medicina, Universidade de São Paulo; 2016.

Introdução: $\mathrm{O}$ câncer de orofaringe representa 10 a $12 \%$ entre todos os tumores malignos do trato aero digestivo superior com incidência crescente nos Estados Unidos e Europa. O Papillomavírus humano (HPV) está associado aos tumores de orofaringe em até 63\%, promovendo uma evolução e prognóstico melhor. Objetivo: Descrever a prevalência do HPV em carcinomas de células escamosas de orofaringe tratados por cirurgia. Analisar a associação entre a presença do HPV e as características demográficas, clínicas, patológicas e terapêuticas. Avaliar a importância da presença do HPV na sobrevida livre de doença e sobrevida global. Método: Pesquisamos a presença do Papillomavirus humano, por PCR, no anátomo patológico. A descrição da amostra foi realizada através de média, frequência absoluta e relativa. Foi estimada a prevalência do HPV e seu respectivo intervalo de $95 \%$ de confiança. A análise da associação entre a presença de HPV e as características demográficas, clínicas e patológicas, foi feita pelo teste de associação pelo quiquadrado. A análise da sobrevida livre de doença e sobrevida global foi feita pelo estimador produto limite de Kaplan-Meier e modelos de risco proporcionais de Cox. Resultados: Os pacientes apresentavam idade variando de 34 a 78 anos, com uma média de 56,9 anos. Apenas 10 mulheres no estudo, totalizando com 76 homens. A maioria dos pacientes eram brancos $(83,7 \%)$. Até 6 meses foi o tempo que a maioria dos pacientes apresentaram como início dos sintomas $(69,0 \%)$. O sintoma mais comum foi a odinofagia (38,4\%). A amígadala foi a localização mais frequente 
(69,8\%). Quanto ao estádio clínico, o III e o IV apresentavam a maior frequência (71,4\%). Forma realizadas cirurgias amplas como as bucofaringectomias em 76 pacientes $(88,4 \%)$. O esvaziamento cervical ipsilateral foi realizado em 81 pacientes (94,2\%) e no contralateral em apenas $21(24,4 \%)$. A prevalência do HPV foi de 57\%, e o tipo mais comum foi o 16 , em $83,6 \%$. A única associação estatisticamente significativa entre as variáveis do estudo com o HPV, foi o tabagismo, onde todos os não fumantes apresentavam HPV. As taxas de sobrevida livre de doença foram $73,9 \%, 65,9$ e $57,9 \%$ respectivamente para 12, 24 e 60 meses. Houve diferença estatisticamente significativa com piores taxas, para idade menor que 55 anos e margens comprometidas. A presença do HPV não influenciou a sobrevida livre de doença, nem a sobrevida global. As taxas de sobrevida global foram 75,6\%, 54,7\% e $43,0 \%$, respectivamente aos 12, 24 e 60 meses. Houveram piores taxas para o paciente etilista e com recidiva.Conclusão:A presença do HPV não se mostrou importante, como fator prognóstico, nessa série cirúrgica se o paciente for etilista e ou tabagista.

Descritores: Papillomaviridae; carcinoma de célulasescamosas; orofaringe;análise de sobrevida; estimativa de Kaplan-Meier; modelos de riscosproporcionais; homens; mulheres. 


\begin{abstract}
Menezes RM. Clinical and pathological study and detection of human papillomavirus in oropharynx squamous cells carcinoma submitted to surgery[Thesis]. São Paulo: Faculdade de Medicina, Universidade de São Paulo; 2016.
\end{abstract}

Introduction:Oropharynx cancer is considered to enact approximately 10 to $12 \%$ of the cases among all malignant tumors from the upper aero digestive tract showing significant growth in its frequency rate in The United States and Europe. Human papillomavirus (HPV) is associated to oropharynx cancer in up to $63 \%$ of the cases, promoting better evolution and prognostic.Objective:Describe the prevalence of the HPV in oropharynx squamous cells carcinoma submitted to surgery. Investigate the association between HPV presence and the demographic, clinical, pathologic and therapeutic features. Estimate the importance of the HPV existence on the diseasefree survival and overall survival. Material andMethods: The existence of Human papillomavirus was studied through the use of PCR. The sample account was conducted through average, absolute and relative frequency. It has been estimated the prevalence of HPV and its corresponding 95\% confidence interval. The association analysis between the presence of HPV and the demographic, clinical and pathological features was completed by the Qui-square association test. The disease-free survival timeline and the overall survival were estimated using the product limit estimator Kaplan-Meier and Cox proportional hazards model. Results: The studied patients were aged between 34 and 78, showing an average of 56.9 years of age. There were 
only 10 women in the study, thus presenting 76 men. Most of the patients were white $(83.7 \%)$. It has been ascertained that $69.0 \%$ of the patients presented the symptoms onset up to the sixth month of the disease. The most common symptom among $38.4 \%$ of the cases was odinophagy. In regards to the tumor location $69.8 \%$ were found in the amygdala.Clinical stagings III and IV were found to be the ones with greater representation among patients (71.4\%). Extensive surgeries such as bucopharyngectomy were performed in 76 patients $(88.4 \%)$. In order to treat ipsilateral neck 81 patients underwent neck dissection (94.2\%). Contralateral neck dissection was applied in 21 patients (24.4\%). The prevalence of HPV was of 57\%, and the most common type was 16 , present in $83.6 \%$ of the cases. It was possible to notice smoking as the only statistically significant association, which showed all nonsmoking having HPV. The disease-free survival rates were of $73.9 \%, 65.9 \%$ and $57.9 \%$ to 12,24 and 60 months respectively. The study has shown significant statistical difference with worse rates, to the ones under 55 years of age and presenting compromised margins. HPV presence did not influence the disease-free survival timeline, or the overall survival. The overall survival rates were of $75.6 \%$, $54.7 \%$ and $43.0 \%$ to 12,24 and 60 months respectively. Worse rates were found in alcoholic patients as well as in relapse cases. Conclusion: In these surgical series, HPV existence was not identified as an important prognosis factor when considering smokers and/or alcoholic patients.

Descriptors: Papillomaviridae; carcinoma, squamous cell; oropharynx; survivalanalysis; Kaplan-Meier estimate; proportional hazards models; men; women. 


\section{INTRODUÇÃO}

\subsection{Epidemiologia do câncer de orofaringe}

O câncer de cabeça e pescoço tem sido associado a significativa morbidade e mortalidade em todo o mundo. Considerando-se em conjunto todos os tumores das vias aerodigestivas superiores, é o quinto tipo mais frequente de câncer, com até 780000 casos novos por ano, sendo a oitava causa de mortalidade mundial. No Brasil, o câncer de cavidade oral, é o quinto mais frequente na população masculina, com aproximadamente 11280 casos novos por ano, segundo a estimativa do Ministério da Saúde, para o biênio 2014/2015. Ele representa aproximadamente 10 a $12 \%$ entre todos os tumores malignos do trato aerodigestivo superior e sua incidência vem crescendo numa taxa anual de 2 a 3\% nos Estados Unidos. (Sikora et al., 2004, Lescaille et al., 2011, Betiol J et al., 2013, Hama et al., 2014, Whang et al., 2015)

O carcinoma de orofaringe apresentou aumento nas taxas de incidência, na última década, principalmente o de amígdala. A orofaringe compreende as amígdalas, a base da língua incluindo a valécula, o palato mole e a parede posterior da orofaringe. Cerca de $95 \%$ dos tumores são carcinomas de células escamosas. A maior parte dos pacientes já se apresenta com tumores em estádio avançado, III ou IV, em parte pela discreta sintomatologia nas fases iniciais (Ringström et al., 2002, Ritchie et al., 2003, Sikora et al., 2004, Pedruzzi et al., 2008, Harréus et al., 2010, Lescaille et al., 2011, Dahlstrom et al., 2013, Hauck et al., 2015) e também pela diminuição da sensibilidade da mucosa exposta a fatores agressivos como o tabaco e o álcool, ou ainda pela ação viral (D’Souza et al., 2010). O diagnóstico tardio é associado ao aumento da sua morbidade relacionada ao tratamento e a maior mortalidade. 
O tratamento dos tumores iniciais pode ser feito tanto por meio de cirurgia ou da associação de radioterapia e quimioterapia, enquanto nas fases avançadas geralmente associam-se radioterapia e quimioterapia ou cirurgia, radioterapia e quimioterapia (Lindel et al., 2001, Ritchie et al., 2003, Kumar et al., 2007, Harréus et al., 2010, Brizel et al., 2012).

O câncer de orofaringe está associado ao tabagismo e etilismo em até 90\% dos casos e, em até $85 \%$ dos casos, está associado ao papillomavirus humano (HPV). Nos últimos anos têm-se observado aumento da incidência desse câncer particularmente em indivíduos jovens, não tabagistas e não etilistas (Lindel et al., 2001, Klussmann et al., 2001, Andrews et al., 2009, Lescaille et al., 2011). Esse aumento da incidência pode estar relacionado com mudanças nos hábitos sexuais, levando se em conta as campanhas antitabágicas. Aproximadamente $86 \%$ do HPV associado ao câncer de orofaringe é do tipo 16 (Attner et al., 2010).

Em 2007, um estudo do IARC (International Agency for Research on Cancer), concluiu haver suficiente evidência que o HPV é carcinogênico na cavidade oral e orofaringe, com limitada ação em relação à laringe (Attner et al., 2010, Betiol J et al., 2013). Atualmente o câncer de orofaringe HPV positivo, é considerado uma entidade diferente do câncer de orofaringe HPV negativo, baseado nas características epidemiológicas, clínicas e biológicas. Esse câncer, o HPV positivo, está associado com menor consumo de álcool e tabaco, com pacientes mais jovens e vida sexual ativa, com índice de recidiva loco regional e segundo tumor menores, e com sobrevida global e livre de doença maiores (Sikora et al., 2004, D’Souza et al., 2010, Allen et al., 2010, Adelstein et al., 2010, Marur et al., 2010, Snow et al., 2010, Rietbergen et al., 2013, Hauck et al., 2015). 
Muitas vezes o diagnóstico do tumor é confirmado apenas em estádio clínico avançado, e mesmo assim, o prognóstico em relação à sobrevida global e livre de doença do câncer de orofaringe HPV positivo é melhor que o observado nos casos HPV negativos. Nos pacientes, carcinomas HPV negativos, a sobrevida permanece em média, em torno de $50 \%$ em cinco anos, sendo a recidiva loco regional a principal causa de falha no tratamento ou um segundo tumor primário. (Klussmann et al., 2001, Ringström et al., 2002, Ritchie et al., 2003, Gillison, 2004, Licitra et al., 2006, Fakhry et al., 2008, D’Souza et al., 2010, Castro Júnior et al., 2013).

Análises realizadas em populações de algumas cidades da costa oeste dos Estados Unidos inferiram que a incidência de câncer de orofaringe HPV positivo aumentou 225\% no período de 1988 a 2004, enquanto que a incidência do câncer HPV negativo declinou em $50 \%$. Como consequência a incidência média geral foi $28 \%$ maior. Nas mesmas cidades no período 2003 a 2004 a prevalência do HPV nos tumores de orofaringe era em média de 70\% (Chaturvedi et al., 2011)

Estima-se que até 2020 o número anual de casos de câncer de orofaringe ultrapasse o de câncer de colo uterino nos Estados Unidos. Considerando-se uma taxa de prevalência em torno de $70 \%$, o número de tumores HPV positivos também ultrapassará o de câncer de colo uterino e ainda será o de maior incidencia entre todos os tumores na cabeça e pescoço (Chaturvedi et al., 2011)

Nos casos de pacientes com carcinoma de células escamosas de orofaringe tratados inicialmente por cirurgia os principais fatores prognósticos são o estádio clínico, margens cirúrgicas e a presença de metástases linfonodais. Alguns marcadores moleculares foram estudados, como o p53, o EGFR e o p16, porém sua importância prognóstica não está estabelecida e estas informações não são utilizadas na clínica para 
decisão terapêutica. Alguns estudos retrospectivos confirma o papel prognóstico da infecção por HPV em séries de casos tratados por cirurgia (Weinstein et al., 2012, Quon et al., 2013b, Masterson et al., 2014, Almeida et al., 2014). Estudos sobre HPV em séries cirúrgicas são escassos e até o presente não se têm consenso sobre a utilidade clínica do status HPV para a intervenção cirúrgica como de tratamento adjuvante (Licitra et al., 2006, Kong et al., 2009, Jo et al., 2009, Harréus, 2010).

Também em séries de pacientes submetidos a radioterapia, ou associação radioterapia com quimioterapia, confirma-se a importância prognóstica da infecção por HPV. Este efeito deve-se ao aumento de sensibilidade dos tumores HPV positivos ao tratamento radio e quimioterápico (Lindel et al., 2001, Fakhry et al., 2008, Jo et al., 2009, Adelstein et al., 2010, Snow et al., 2010, Dahlstrom et al., 2013, Rieckmann et al., 2013). Por esta razão tem-se recomendado que o status de HPV seja melhor estudado. Diversos ensaios clínicos em andamento levam em conta o status HPV para avaliar o impacto de diferentes modalidades de tratamento inicial menos agressivas (BoscoloRizzo et al., 2013, O’Sullivan et al., 2013, Rietbergen et al., 2013, Quon et al., 2013a, Masterson et al., 2014).

\subsection{Papillomavírus Humano (HPV)}

O papillomavirus humano (HPV) é um vírus da família Papillomaviridae, contém aproximadamente oito mil pares de bases no seu genoma circular de dupla fita, cercado por cápsula protéica de setenta e dois capsômeros, com configuração icosaédrica, medindo cerca de cinquenta e cinco nanômetros, e não envelopado. O DNA do HPV codifica sete ou oito proteínas precoces (E1 a E8) e duas proteínas tardias (L1 e L2). As precoces E1, E2, E4, E5, E6 e E7, não são estruturais e estão implicadas na regulação, replicação e patogênese. Uma região reguladora contém as sequências de 
controle para a transcrição, a sequência $N$-terminal partilhada para proteínas precoces e origem da replicação. As tardias são estruturais e formam o capsídeo. (Boyle et al., 1973, Murray et al., 2009, Lescaille et al., 2011, Rampias et al., 2014, Dalianis, 2014b, Panwar et al., 2014).

Foram identificados aproximadamente cento e setenta tipos de HPV, a maioria encontrada na pele e outros em menor frequência, nas mucosas. A árvore filogenética baseada na sequencia do nucleotídeo homólogo da proteína capsídea L1, agrupa os diferentes tipos de HPV em cinco gêneros. No gênero alpha são encontrados os tipos que afetam as mucosas enquanto os outros gêneros abrigam os tipo encontrados na pele. O tipo mucoso pode ser dividido em alto e baixo risco. Os HPVs do tipo mucoso podem ser divididos em baixo e alto risco. Estes são o 6 e 11, e estão relacionados com neoplasias benignas, como as hiperplasias papilomatosas e lesões verrucosas. Os tipos de alto risco são $16,18,31,33,35,39,45,51,52,56$ e 58 , relacionados com neoplasias malignas da cabeça e pescoço e da região anogenital. Mais de $90 \%$ dos carcinomas de células escamosas de cabeça e pescoço, HPV associados, são causados pelo tipo 16 (Vassalo et al., 1999, D’Souza et al., 2007, Lescaille et al., 2011, Chung et al., 2013, Dalianis, 2014b, Ramqvist et al., 2015).

Os HPVs são epiteliotrópicos, cujo ciclo de vida está relacionado à diferenciação da célula escamosa. Ocorrendo a infecção, esta pode permanecer latente ou sofrer replicação intranuclear ativa, com síntese de partículas infectantes (Vassalo et al., 1999, Lescaille et al., 2011, Rampias et al., 2014).

\subsection{Patogênese do carcinoma de orofaringe mediado por HPV}

Uma característica do HPV é que seu genoma viral é preservado como DNA epissomal, ou seja, nos tumores benignos ou pré malignos, ele não se integra ao genoma 
do hospedeiro. Entretanto, nos tumores malignos, o DNA viral encontra-se integrado com o hospedeiro. A ruptura do genoma circular no interior das proteínas E1 ou E2, para promover a integração, faz com que estes genes sejam inativados, impedindo a sua replicação viral, mas mantém-se a expressão de outros genes do HPV, incluindo os genes E6 e E7. As proteínas E6 e E7 do HPV 16 e 18 foram identificadas como oncogenes porque ligam e inativam as proteínas supressoras do crescimento celular p53 e pRb. A E6 se liga a p53 e a E7 a pRb, e são importantes para a imortalização e transformação celular. Sem as proteínas supressoras sobre a multiplicação celular, as células ficam mais propensas a mutação ou à ação de um cofator. Elas desregulam a ação antiapoptose e a proliferação celular, causando uma instabilidade genética e levam a superexpressão da ciclina dependente quinase inibidora, a p16, usada como marcador de infecção pelo HPV, por imunohistoquímica, em câncer de orofaringe. Os oncogenes são considerados os principais responsáveis pela instalação e manutenção da transformação maligna dos queratinócitos humanos devido sua ligação e inativação de p53 e pRb. A integração viral representa um passo crítico e necessário para a transformação maligna do epitélio. (Münger et al., 1992, Wilczynski et al., 1997, Miguel et al., 1998, Vassalo et al., 1999, Gillison et al., 2004, Begum et al., em 2005, Hoffmann et al., 2006, Murray et al., 2009, Smith et al., 2009, Adelstein et al., 2010, Allen et al., 2010, Lescaille et al., 2011, Chung et al., 2013, Rampias et al., 2014, Dalianis, 2014b, Panwar et al., 2014).

As infecções causadas pelo HPV são restritas ao sítio inicial da infecção. Elas não são citolíticas e causam pouca ou nenhuma reação inflamatória. As proteínas do HPV são expressas em baixos níveis e em diferentes camadas do epitélio, o pavimentoso estratificado (Junqueira et al., 2008). O vírus acessa a camada basal por lacerações pré-existentes, ou no caso da orofaringe, se especula que o HPV penetra na 
membrana basal do epitélio da tonsila e infecte as células das criptas, as quais são expostas por ruptura do epitélio e da membrana, ocorrendo assim transporte de antígenos, linfócitos e anticorpos. Os genes precoces do vírus estimulam a multiplicação celular facilitando assim a replicação do genoma viral, pela DNA polimerase das células hospedeiras. O aumento induzido pelo HPV no número de células, causa espessamento das camadas basal e espinhosa, levando à formação das lesões com aspecto verrucoso. Conforme as células basais se diferenciam, fatores nucleares específicos promovem a transcrição de diferentes genes virais. Esta é relacionada à expressão de queratinas específicas. Os genes tardios que codificam as proteínas estruturais são expressos apenas na camada superior com diferenciação terminal (Murray et al., 2009, Lescaille et al., 2011, Chung et al., 2013, Rampias et al., 2014).

Em pacientes com carcinoma de células escamosas HPV positivos, foi descrita uma maior reação imunológica antitumoral, mostrando um infiltrado peri e tumoral por linfócitos, bem como um metabolismo consumidor de ácido láctico. Assim eles podem reagir melhor em um ambiente adverso como o da radioterapia (Krupar et al., 2014) .

\subsection{Diagnóstico}

O diagnóstico de HPV pode ser sugerido quando por microscopia óptica, quando se identifica hiperplasia das células espinhosas, hiperqueratose, presença de células epiteliais escamosas (queratinócitos) coilocitóticas, com núcleos condensados e agrupados (Murray et al., 2009). Por imunohistoquímica, identificando-se a expressão de p16, com diaminobenzidina (DAB), estabelece-se um padrão positivo, quando corase de alta intensidade mais de $70 \%$ da célula. Esse método possui alta sensibilidade (97\%), porém tem uma especificidade questionável (82\%), sendo positivo mesmo em tumores HPV negativos, por outros métodos moleculares. Finalmente, por técnicas de 
biologia molecular, sendo as mais padronizadas e utilizadas a hibridização in situ (HIS), com alta sensibilidade (94\%) e especificidade (91\%), a reação em cadeia da polimerase (PCR), com alta sensibilidade (91\%) e baixa especificidade (87\%), e E6 /E7 mRNA com alta especificidade e sensibilidade, por RT-PCR, mas podendo requerer material congelado (Vassalo et al., 1999, Allen et al., 2010, Dreyer et al., 2013, Schache et al., 2013, Bussu et al., 2014, Dalianis, 2014a).

O PCR é considerado um dos métodos mais sensíveis, podendo ser utilizado em material incluído em parafina ou citológico arquivado. Além de alta sensibilidade, identificando até uma cópia viral, a técnica é relativamente simples após sua instalação em laboratório, sendo realizada por aparelho que pode efetuar vários exames ao mesmo tempo. Porém sua maior qualidade é o seu ponto mais vulnerável, pois sua sensibilidade pode resultar em falsos positivos, por contaminantes do próprio laboratório. Alguns estudos associam o p16 ao PCR, aumentando assim a eficácia diagnóstica (Vassalo et al., 1999, Allen et al., 2010, Lescaille et al., 2011, Dreyer et al., 2013).

Considerando-se que o carcinoma de orofaringe é frequente na população brasileira, e que estudos recentes mostram aumento do número de casos relacionados à infecção por HPV (Gillison, 2009, Attner et al., 2010, Dahlstrom et al., 2013, Bose et al., 2013, Panwar et al., 2014, Näsman et al., 2015, Lewis et al., 2015) e que sua importância na terapêutica desses tumores, não está estabelecida, principalmente nos pacientes tratados com cirurgia, propusemos pesquisar a associação entre a infecção por HPV nos carcinomas de células escamosas de orofaringe tratados com cirurgia, do AC Camargo Cancer Center. Estas informações poderão ser úteis para o diagnóstico, terapia, rastreamento dos casos e prevenção. Pode se ainda considerar as possibilidades de tratamento personalizado, uma melhor sobrevida e qualidade de vida com propostas de desintensificação do tratamento nos carcinomas de células escamosas HPV positivos, 
principalmente porque estão associados a uma doença diagnosticada em idade mais jovem que os carcinomas da mesma topografia diagnosticados em tabagistas e etilistas (Hong et al., 2010, Turner et al., 2011, Kofler et al., 2014, Kreimer, 2014, Fakhry et al., 2014, Psyrri et al., 2014, Laskar et al., 2015). 


\section{OBJETIVOS}

2.1. Descrever a prevalência do HPV em carcinomas de células escamosas da orofaringe tratados por cirurgia.

2.2. Analisar a associação entre a presença do HPV e as características demográficas, clínicas, patológicas e terapêuticas.

2.3. Avaliar a importância da presença do HPV na sobrevida livre de doença e sobrevida global. 


\section{REVISÃO DE LITERATURA}

Em 1973, Boyle et al., foram os primeiros a identificar por microscopia eletrônica, partículas virais intranucleares, pertencentes ao grupo do papova vírus, em papiloma de laringe. Não conseguiram a replicação celular, porém formularam a hipótese de estar relacionada a alguns casos de transformação maligna da papilomatose.

Foi Syrjänen et al., em 1982, os primeiros a relacionar a presença do HPV, em carcinomas de células escamosas de laringe com a sua capacidade de transformação maligna, associando-o aos papilomas pré-existentes. A pesquisa foi feita por imunohistoquímica, revelando-se presente em 36\% dos casos.

Em 1997, Wilczynski et al., estudaram se a presença do HPV por PCR e HIS, influenciaria a morfologia ou a expressão oncogênica no carcinoma de células escamosas de amígadala. A expressão oncogênica foi estudada por imunohistoquimica, além da expressão de p53, pRB, e ciclina D1. A presença do HPV sugeriu que há uma predileção por células escamosas não queratinizadas ou que até haveria uma transformação viral inibindo a queratinização das células tumorais. Houve também a associação entre o HPV e a diminuição da expressão da ciclina D1, pRB e p53, compatíveis com os efeitos das oncoproteínas virais.

Miguel et al., em 1998, estudaram a presença do HPV por PCR, em 45 pacientes com carcinoma de células escamosas de cabeça e pescoço, sendo 10 de hipofaringe, 17 de cavidade oral, 11 de orofaringe, 7 de laringe e 1 de seio maxilar. Encontraram uma baixa prevalência $(11 \%)$ e todos eram HPV 16. Concluíram nessa causuística não ser importante o HPV para a carcinogênese de vias aerodigestivas superiores, e que predominava a importância do álcool e tabaco no Brasil. 
Gillison et al., em 2000, investigaram o papel do HPV em uma extensa série de 253 pacientes com carcinoma de células escamosas de cabeça e pescoço, usando a PCR, hibridização por Southern blot e HIS, com os seguintes resultados: HPV detectado em 25\% dos casos, sendo o HPV 16 presente em 90\% destes casos. Um menor grau de diferenciação tumoral e a localização em orofaringe, independente um do outro, propiciava uma maior probabilidade de positividade para o HPV. O câncer de orofaringe quando positivo para o HPV, estava associado em pacientes que consumiam bebidas alcoólicas com menor ingestão de quantidade de álcool diariamente e também menor consumo de tabaco. Estes casos estavam associados ao tipo basalóide epitelial e uma melhor sobrevida, chegando até $59 \%$ de redução do risco de morte por câncer, após ajuste por estadiamento, consumo de álcool e idade maior que 60 anos, quando comparados com o HPV negativos. Sugeriram então que possivelmente os casos de câncer de orofaringe HPV positivos deveriam ter abordagens terapêuticas distintas dos casos de câncer de orofaringe HPV negativos.

Klussmann et al., em 2001, foram os primeiros a avaliar a carga viral do DNA do HPV 16, por PCR, em carcinomas de células escamosas de cabeça e pescoço, no sítio primário e nas metástases linfonodais, encontrando $26 \%$ de positividade. A mucosa normal desses pacientes também foi pesquisada, detectando ser positiva para o HPV em 64\% dos pacientes. De acordo com a localização foi assim distribuído: $18 \% \mathrm{em}$ cavidade oral, $45 \%$ em orofaringe, $25 \%$ em hipofaringe, $8 \%$ em nasofaringe e $7 \%$ para laringe. O HPV 16, foi encontrado em 58\% dos casos positivos. De acordo com a casuística, a maioria dos pacientes com carcinomas HPV positivos ou não, eram tabagistas e etilistas, ou consumiam tabaco e álcool em baixa quantidades. Nesses casos HPV positivos, o grau de diferenciação epitelial tumoral era menor. Dos 20 pacientes com carcinoma de células escamosas de amígdala, HPV positivos, submetidos a 
tratamento cirúrgico, somente $28 \%$ não obtiveram controle local da doença. Portanto mostrando-se um resultado diferente da evolução observada nos casos dos carcinomas de amígdala HPV negativos. Os níveis de detecção do HPV e carga viral nas metástases e no tumor primário eram iguais. A quantificação da carga viral do HPV 16 mostrava uma carga média comparável a outras doenças tumorais malignas associadas ao HPV, como o carcinoma anogenital.

Em 2001, Lindel et al., também estudaram infecção pelo HPV nos carcinomas de células escamosas de orofaringe, seu efeito e prognóstico no tratamento por radioterapia. Pesquisaram a presença do vírus pelo PCR e a integridade viral do gene E2 em 99 pacientes. Encontraram apenas 14\% de positividade do HPV, ligada mais ao gênero feminino, faixa etária acima de 56 anos, não fumantes e não etilistas. O HPV positivo indicava o melhor controle loco regional e assim uma boa resposta ao tratamento com radioterapia.

Ringström et al., em 2002, obtiveram de uma série de oitenta e nove pacientes com carcinoma de células escamosas de cabeça e pescoço, $20 \%$ de positividade para o HPV16 por PCR, sendo que 64\% estavam localizados na amígdala, aparecendo na faixa etária mais jovem, com consumo de álcool mais leve, porém não associados com estádio clínico, grau de diferenciação tumoral, metástases regionais e tabagismo.

Ritchie et al., em 2003, estudaram 139 portadores de carcinoma de cabeça e pescoço, não apenas de células escamosas, e detectaram 21\% de HPV positivo e destes, 83 eram do tipo 16. O estudo também associou a presença do HPV com uma melhor sobrevida global em até um terço nos pacientes do gênero masculino.

Begum et al., em 2003, estudaram a detecção do HPV em linfonodos cervicais como uma estratégia de localização tumoral, em caso de metástases com tumor primário 
oculto. Haveria uma predileção do vírus, ao sítio de orofaringe. Realizaram PCR, HIS e imunohistoquímica para o p16 em pacientes com câncer de orofaringe e compararam com os sítios de laringe e hipofaringe, tentando assim uma provável localização nos casos de tumor primário oculto, pois nos casos de tumores não localizados na orofaringe, a pesquisa de HPV era negativa.

Smith et al., em 2004, estudaram outros possíveis fatores de risco associados ao HPV em 193 casos de carcinomas de cavidade oral e orofaringe. Utilizaram o PCR, sequenciando dso DNA e encontraram 20\% de HPV positivo. A este fato foi associado faixa etária mais jovem, com maior número de parceiros sexuais e atividade sexual orogenital.

Gillison, em 2004, publicou uma importante revisão realçando as características epidemiológicas, clínicas e moleculares, no carcinoma de células escamosas de cabeça e pescoço HPV positivos. Descreveu este como uma entidade distinta do carcinoma de células escamosas HPV negativo. Relatou também o aumento da incidência dos tumores de orofaringe, principalmente amígdala nos Estados Unidos, em caucasianos e afro americanos. Este aumento foi registrado nas últimas décadas, ainda que o consumo de álcool e tabaco tenha diminuído nesse mesmo período como resultado de campanhas educativas. Certamente as mudanças no comportamento sexual, podem ter contribuído para o aumento da incidência dos tumores de amígdala. Enfatizou a ação do HPV como oncogênico e sexualmente transmissível não só nos tumores anogenitais descritos anteriormente como também nos tumores da cabeça e pescoço. A característica molecular dos tumores HPV positivos inclui entre outras, expressão de E6 e E7, do p53 selvagem, diminuição da expressão da ciclina D e pRb, e aumento da expressão da p16, ao contrário dos casos HPV negativo. Quanto ao prognóstico, observou-se uma redução de 59\% do risco de morte pelo câncer de cabeça 
e pescoço no HPV positivo em relação ao negativo. Sugeriu que no futuro a vacina fosse utilizada como profilaxia ou mesmo terapia. Em uma nova revisão, Fakhry e Gillison (2006), reconheceram mais uma vez a oncogênese do HPV, e principalmente o HPV 16, no carcinoma de células escamosas de cabeça e pescoço, principalmente nos localizados na orofaringe. Os pacientes com tumores HPV positivo eram de faixa etária mais jovem, geralmente não fumantes e não etilistas, associados com mudanças nos hábitos sexuais, havendo então essa transmissão para a orofaringe. Concluíram ser de grande importância a detecção do HPV nos pacientes com carcinoma de orofaringe, porque eles estão associados a um melhor prognóstico e sobrevida, em pelo menos duas vezes, mesmo diagnosticados em um estádio clínico mais avançado. Destacaram a importância do rastreamento e prevenção nos tumores de cabeça e pescoço.

Begum et al., em 2005, estudaram a detecção do HPV 16 por HIS em 166 pacientes com carcinoma de células escamosas de cabeça e pescoço para analisar a integração viral no tumor. Detectaram HPV em $22 \%$ dos casos, chegando a $82 \%$ no sítio tonsilar. Houve forte evidência de a integração viral estar associada ao processo carcinogênico na orofaringe, já que não observaram o mesmo achado no tecido normal.

Em 2006, Smith et al., pesquisaram em 204 pacientes portadores de carcinoma de células escamosas e adenocarcinomas a resposta sorológica aos anticorpos HPV16 VLP e anticorpos HPV16 E6 e E7 e compararam os resultados, com os achados de PCR. Relacionaram a positividade sorológica do HPV E6 e E7 em 33,8\% enquanto 26,1\% ao PCR, sugerindo assim que esse possa representar um marcador biológico específico para o HPV, pois também estaria relacionado com os tumores de sítio de origem mais frequente (orofaringe), estádio clínico mais avançado, linfonodos mais comprometidos e baixo grau de diferenciação tumoral. 
Hoffmann et al. (2006), estudaram a relação entre a presença de células T específicas para HPV 16 E7, nos pacientes com carcinoma de células escamosas da orofaringe e encontraram um aumento significante nos pacientes com tumores HPV positivos, confirmados por PCR, em relação aos pacientes com o mesmo carcinoma de orofaringe, porém HPV negativos. A análise foi realizada no sangue periférico.

Perrone et al., em 2007, estudaram o polimorfismo do gene Tp53 no códon 72, em 77 pacientes com carcinoma de células escamosas em orofaringe, HPV positivos e negativos e encontraram uma maior taxa $(25 \%)$ do genótipo PP, no Tp53, entre os casos HPV positivos. Concluíram então que essa associação possa ser um fator de risco para o desenvolvimento do carcinoma de células escamosas entre as mulheres e o tipo mais frequente foi o HPV 16.

Fakhry et al., em 2008, estudaram mais uma vez o impacto do HPV positivo na sobrevida nos pacientes portadores de carcinoma de células escamosas de cabeça e pescoço. O estudo prospectivo foi realizado em 96 pacientes com tumores em estádio clínico III ou IV, de orofaringe ou laringe, os quais foram tratados com quimioterapia de indução e em seguida com quimioterapia adjuvante e radioterapia fracionada. A presença do HPV foi determinada pelo PCR e HIS. Os pacientes com tumores HPV positivos tiveram uma melhor resposta a quimioterapia de indução ( $82 \%$ x 55\%) e após a quimio-radioterapia adjuvante $(84 \%$ x $57 \%)$. Também observaram uma sobrevida melhor. Concluíram assim que nesse estudo prospectivo os pacientes com tumores HPV positivos tiveram tanto taxas de resposta terapêutica como de sobrevida melhores.

Jo et al., em 2009, também em um estudo prospectivo fase II, estudaram a presença do HPV-16 por PCR em biópsias a fresco de tumores de cabeça e pescoço, e relacionaram à resposta ao tratamento e sobrevida. Recomendaram que os pacientes com tumores HPV positivos fossem submetidos a terapêutica multimodal. 
Andrews et al. (2009), estudaram objetivamente se a infecção por HPV de alto risco (HPV16 e HPV18), estaria associada ou não com câncer de orofaringe em pacientes não fumantes e não etilistas. Pesquisaram em 40 pacientes, não fumantes e não etilistas, e utilizaram 18 casos de câncer de orofaringe e 22 lesões benignas como controle. Realizaram PCR e PCR-RT no material de biópsia para pesquisa do HPV. Dos pacientes controles a metade possuía história prévia de câncer. A análise estatística analisando os casos com câncer de orofaringe, concluiu que estes apresentavam 6,1 vezes mais chances de apresentarem-se HPV positivos do que os controles. Assim, o HPV foi encontrado em 14 de 18 casos de câncer de orofaringe e 6 de 22 casos controles. Outrassim, $78 \%$ dos casos positivos eram tumores da orofaringe, e em $30 \%$ das lesões benignas, dos quais todos possuíam história prévia de câncer. Vinte e cinco por cento dos pacientes controles, tinham tumores HPV positivos, os quais não apresentavam história prévia de câncer. Esse estudo também serviu para a validação do PCR-RT, o que se confirmou nas amostras de pequeno tamanho como biópsias, ser tão eficiente como o PCR. Como foi encontrado também nas lesões benignas com história prévia de câncer, os autores sugeriram acompanhar de perto esses casos com tumores HPV positivos. Sugeriram também a vacinação preventiva para diminuição da incidência do câncer de cabeça e pescoço, e a terapêutica para diminuição do risco de recidiva, por infecção latente.

Attner et al., em 2010, estudaram primeiramente em 95 pacientes, a incidência e a prevalência do HPV no carcinoma de células escamosas no câncer de base de língua, na Suécia. Estudaram por PCR e PCR-RT, as biópsias obtidas, no período de 1970 a 2007. A prevalência do HPV aumentou de 58\% no período de 1998 a 2001, para 84\% de 2004 a 2007. Em 86\% o HPV 16 foi o tipo mais observado, porém o tipo 33 foi detectado em 10\%. Não houve variação quanto à idade, não ocorreram em indivíduos 
mais jovens, nem houve variação quanto ao sexo ou grau de diferenciação histológica, entre os grupos com carcinomas HPV positivos ou negativos. Os casos HPV positivos apesar de ser diagnosticados em estádio clínico mais avançado, porém só em relação aos linfonodos e não ao tamanho do tumor primário. Houve também um aumento na incidência do HPV no câncer de base de língua de 0,15/100 000 no período de 19701974 para 0,47/100 000 no período de 2004-2007. Os autores argumentaram que estes resultados não se deviam a viés da melhoria de coleta e armazenagem do DNA, pois em $100 \%$ eles conseguiram amplificá-lo. Baseado neste estudo, a International Agency for Research on Cancer (IARC, 2007) reconheceu a infecção por HPV como fator de risco para o câncer de orofaringe. Este grupo não só concluiu que há um aumento na incidência do câncer de base de língua, na Suécia, como também o HPV foi o responsável. Apesar do número limitado de casos, concluíram também ser o prognóstico mais favorável nos paciente com tumores HPV positivos.

D’Souza et al., em 2010, compararam o valor dos fatores preditivos demográficos e comportamentais dos pacientes com tumores de cabeça e pescoço, HPV positivos e negativos. Detectaram o HPV por exame de HIS nos tumores, realizaram análise sorológica e PCR-RT nas células esfoliadas da mucosa oral em 255 pacientes com câncer de cabeça e pescoço, sendo 119 de orofaringe. Foram estudados idade, gênero, etnia, consumo de tabaco e número de parceiros sexuais. Dos 119 pacientes com carcinomas de orofaringe, $71 \%$ tinham tumores positivos para HPV16, contrastando com 5\% dos casos não-orofaringe. Confirmou-se nessa casuística que os casos com tumores HPV positivos em relação aos HPV negativos, eram pacientes mais jovens (média de 52 anos contra 60 anos), brancos (93\% x 82\%), tinham renda maior que U\$ 50 000/ano (70\% x 48\%), com histórico de já haver apresentado alguma doença sexualmente transmissível (34\% x 17\%) e com um número maior de parceiros sexuais. 
Em contrapartida os fatores menos comuns associados aos pacientes com tumores HPV positivos eram a higiene oral precária e tabagismo, embora nestes últimos se o consumo fosse mais pesado, os tumores apresentados, eram associados ao HPV. Observaram também que o tipo histológico mais frequentemente associado ao HPV positivo é o carcinoma de células escamosas, pouco diferenciado. Concluíram ainda que embora alguns fatores demográficos estejam associados com o status HPV, eles apenas servem para supor o status HPV. Há de se utilizar os biomarcadores para o HPV para o diagnóstico preciso. O status HPV não pode ser presumido diante das suas características demográficas ou comportamentais e menos ainda diminuir a intensidade do tratamento tendo como base estas características.

Adelstein e Rodriguez, em 2010, em revisão, reconheceram que a presença do HPV no carcinoma de células escamosas de orofaringe, mudou o paradigma do prognóstico para melhor e futuros ensaios clínicos deveriam estudar atentamente esse fato, e analisar esses grupos de tumores separadamente dos tumores HPV negativos. Junto ao melhor prognóstico, a desintensificação do tratamento poderia acarretar uma menor morbidade, com menos sequelas. A vacina para o HPV poderia ter um papel na prevenção, o que também poderá ser estudado futuramente.

Também em 2010, Allen et al., fizeram uma extensa revisão enfocando o papel etiológico do HPV no desenvolvimento do câncer de cabeça e pescoço e principalmente orofaringe, desde a infecção viral e sua posterior transformação. Discutiram o papel das proteínas precoces E1 e E2, do HPV, envolvidas na replicação do DNA e das proteínas oncogênicas E6 e E7 agindo em p53 e pRb respectivamente, bloqueando as suas ações. E7 bloqueia também a atividade promotora do interferon alfa e beta, diminuindo a sinalização proinflamatória, alterando a modulação das células $\mathrm{T}$ no microambiente tumoral, em pacientes com com tumores HPV positivos, provocando mudanças no 
sistema imunológico. Reforçaram ser a integração do DNA do HPV com o do hospedeiro um passo crucial para a progressão de displasia para câncer. Além do papel oncogênico do HPV, descreveram minuciosamente os métodos diagnósticos moleculares e suas sensibilidades e especificidades e ainda as dificuldades de cada método. Reafirmaram ser o PCR, o padrão ouro para o diagnóstico, apesar da baixa especificidade, em material parafinado. Quanto às implicações clínicas e prognósticas da presença do HPV no câncer de orofaringe, relataram uma melhor sobrevida livre de doença e sobrevida global. A revisão mostra também ser este resultado independente da modalidade de tratamento.

Ang et al., em 2010, estudaram em relação à sobrevida global, 266 pacientes com câncer de orofaringe tratados no período de 2002 a 2005 nos Estados Unidos, comparando radioterapia fracionada, standart com aceleração e boost, e ambos com a utilização de cisplatina (quimioterapia adjuvante). Classificaram os casos em baixo, intermediário e alto risco, de acordo com status HPV, tabagismo e estadiamento. Assim o paciente seria considerado de baixo risco se o tumor fosse HPV positivo, não fumante ou até 10 maços/ano, e estadiamento linfonodal N0-N2a; de risco intermediário se HPV positivo, porém fumante de até 10 maços/ano e com estadiamento linfonodal N2b-N3 ou HPV negativo, fumante até 10 maços/ano com tumor estadiado T2 ou T3. Finalmente, os pacientes seriam classificados como de alto risco com HPV negativo, fumantes e com tumores estadiados como T4. Os pacientes de baixo risco apresentaram 93\% de sobrevida global em 3 anos, os de risco intermediário apresentaram 70,8\% e os de alto risco 46,2\%. Ao realizar esta classificação interagindo essas três características criou-se um algoritmo importante utilizado por vários autores em trabalhos posteriores.

Hong et al., em 2010, analisaram 198 pacientes portadores de carcinoma de células escamosas de orofaringe, de estádio avançado (III e IV), tratados primariamente 
com cirurgia ou radioterapia, em relação à presença do HPV. A prevalência do HPV foi de $42 \%$. Com a presença deste houve um melhor controle loco regional e uma melhor sobrevida livre de doença e global. Nos grupos HPV positivos, fossem eles os pacientes tratados por cirurgia e radioterapia adjuvante (110), somente com radioterapia (24), ou com radioterapia e quimioterapia (47), os pacientes HPV positivos apresentavam 1/3 a menos de chance de recidiva ou óbito do que os pacientes HPV negativos.

Lescaille et al., em 2011, estudaram a relação entre o HPV e o câncer de vias aerodigestivas superiores, em particular os de orofaringe, descrevendo a sua epidemiologia e ressaltando o melhor prognóstico dos casos HPV positivos. Descreveram com particularidades a oncogênese viral e o porque da provável maior incidência na amígdala. Acreditam que por haver invaginações profundas no epitélio da amígdala (as criptas) assim como há na cérvice uterina, haveria a retenção das partículas virais e captura dos antígenos. Ainda enfatizaram não ser a PCR a sinalizadora da integração viral e sim o p16. Sobre o tratamento, visando o paciente com câncer de orofaringe HPV positivo sugeriram a possibilidade do emprego de um tratamento menos tóxico, devido a sua sensibilidade à radioterapia e quimioterapia, provavelmente a ação inativadora destes em E6 e E7, regenerando a ação do p53 e pRb. Por último propõem a vacinação profilática a ser feita também nos meninos para evitar o câncer de orofaringe no futuro, principalmente levando em conta que a incidência nos homens é maior numa proporção de 3:1.

Kreimer et al., também em 2011, publicaram um estudo inédito, amplo e multicêntrico, envolvendo três países, Estados Unidos, México e Brasil, onde estudaram a epidemiologia da infecção do HPV na mucosa oral e orofaríngea de 1680 homens saudáveis. Excluíram pacientes que já haviam sido tratados por doença sexualmente transmissível ou câncer na região anogenital, porém sem excluir câncer de cabeça e 
pescoço prévio. O estudo previa que os pacientes deveriam comparecer por dez consultas a cada seis meses por quatro anos. Caracterizaram demograficamente por idade, uso de tabaco, raça, etnia, estado civil, número de parceiros, comportamento sexual, homo ou heterossexual prática de sexo oral e anal. Coletaram DNA por enxágue bucal e estudaram por PCR. O HPV foi detectado em 4\% dos casos, sendo que os tipos carcinogênicos em 1,3\%. Concluíram ser o HPV associado ao hábito do tabagismo, aumentando a sua incidência conforme a faixa etária cresce, o contrário do que acontece no câncer de cérvix. A associação com o fumo talvez ocorra por diminuição da resposta imunológica ao HPV, por sua ação deletéria direta nas células, mas o aumento em relação à faixa etária ainda necessitaria maiores estudos. Os hábitos sexuais não interferiram significativamente na prevalência do HPV.

As características clínicas dos pacientes que desenvolvem mais de um tumor associado ao HPV foi descrita por Skinner et al., em 2013, tentando entender o mecanismo pelo qual alguns pacientes retêm o vírus e apresentam um segundo tumor e outros não. Estudaram 143 pacientes com 300 tumores HPV relacionados, suas características demográficas, segundo tumor primário e dados de seguimento. A média de tempo para o diagnóstico do primeiro tumor primário foi de 18,5 anos, e para o segundo foi de 3,2 anos. Noventa e três por cento eram mulheres e $62 \%$ dos primeiros tumores primários eram câncer de colo de útero; seguido do segundo primário, câncer de cabeça e pescoço. Quando este era o primeiro primário em $58 \%$, ele era seguido por câncer de colo uterino em 11\%. Um total de 9 pacientes apresentavam tumor sincrônico. Encontraram uma média de 11 anos para o desenvolvimento do segundo primário, principalmente em mulheres em que o tumor de colo uterino era o primeiro primário. Estas pacientes geralmente apresentaram o câncer numa faixa etária mais jovem. Os pacientes não fumantes também mostraram maior intervalo de tempo até o 
aparecimento do segundo tumor primário. Concluíram que não se pode parar, e sim intensificar o seguimento das pacientes tratadas de câncer de colo uterino devido ao risco de ocorrência do desenvolvimento do segundo tumor.

Bussu et al., em 2013, investigaram a possibilidade de ser o p16 um marcador da presença do HPV para o carcinoma de céluas escamosas de cabeça e pescoço, comparado com outras técnicas de biologia molecular. Para tanto pesquisaram-no em biópsias à fresco de 109 pacientes com carcinoma de células escamosas de várias regiões da cabeça e pescoço como hipofaringe, laringe, cavidade oral e orofaringe, e compararam o resultado obtido com a pesquisa do p16 (em material parafinado), mRNA E6 e E7, e captura híbrida de DNA, do HPV. Setenta e três por cento dos pacientes apresentavam tumores em estádio clínico avançado (III e IV). O tipo mais encontrado foi o HPV16. A concordância entre os métodos diagnósticos moleculares foi de quase 100\%, porém quando comparados ao p16, os resultados não foram coincidentes. Assim, em hipofaringe, o p16 era positivo e o HPV RNA e DNA eram negativos. Em laringe, o p16 era positivo em até $4,22 \%$ dos casos, em contraste com $13,3 \%$ de positividade com as técnicas moleculares. Em cavidade oral os métodos moleculares encontraram carcinomas HPV positivo em $12,5 \%$ enquanto a positividade para p16 variou de 2 a $8,5 \%$. Em tumores da orofaringe o resultado obtido foi de $50 \%$ positivo para as técnicas moleculares enquanto somente $6,46 \%$ eram p16 positivos. Concluíram que o mRNA deve ser o padrão ouro para detecção em material fresco e, para material parafinado, os métodos para detecção de DNA sozinhos ou associados são os mais adequados.

Castro Junior et al., em 2013, fizeram uma ampla revisão da biologia molecular dos tumores de cabeça e pescoço, destacando os fatores carcinogênicos ligados ao seu desenvolvimento, a exposição a carcinógenos químicos oriundos do tabaco e álcool, e o HPV. O tipo mais frequente é o 16, em aproximadamente 95\% dos casos. O HPV é o 
agente etiológico em $25 \%$ dos casos de carcinomas de células escamosas de cabeça e pescoço. Em orofaringe está associado em até $60 \%$ dos tumores.

Dahlstrom et al, em 2013, realizaram uma ampla revisão com 3891 pacientes com câncer de orofaringe tratados no MD Anderson Cancer Center, no período de 1955 a 2004. Relataram ter a faixa etária dos pacientes, diminuído nos últimos dez anos (1995-2004) e, enquanto antes de 1995 somente 1/3 eram não tabagistas, depois de 1995 esse número aumentou para 2/3. Também depois de 1995, a distribuição por região da orofaringe, que antes era equitativa, passou a se concentrar na amígdala e base de língua em $85 \%$. Os pacientes submetidos à análise de sobrevida global foram 2299 , por estes não apresentarem metástases à distância. O status HPV só foi verificado nos pacientes tratados nos últimos dez anos e era positivo por PCR em 74\% deles. Concluíram haver uma melhora da sobrevida para os pacientes tratados nos últimos dez anos, e esta ser dependente do status HPV, tabagismo decrescente e estádio clínico. Sugeriram incluir o status HPV no estadiamento.

Chung et al., publicaram em 2013, uma extensa revisão da epidemiologia do HPV, destacando a sua biologia viral, seu mecanismo de infecção e a prevalência. Esta é bem mais baixa em tumores de cavidade oral e orofaringe do que na região anogenital. Nesta, é de 27 a 43\% entre as mulheres de 14 a 59 anos, nos Estados Unidos, e de 0,9 a 7,5\% para a mesma faixa etária, em cavidade oral e orofaringe. Mesmo baixa, estima-se em 2.130.000 o número de pessoas infectadas nos EUA. O mecanismo de transmissão oral ainda não é totalmente claro mas, a prática do sexo oral e o beijo na boca à francesa, contribuem para essa transmissão. A história natural da infecção pelo HPV, mostra que pode haver cura de 8 a 12 meses após o contato, permanecendo apenas $10 \%$ dos casos com infecção persistente, na região anogenital. O mesmo pode ocorrer em orofaringe. Os fatores de risco para infecção são: sexo masculino, ter comportamento 
sexual de risco com vários parceiros e sem proteção, e fumantes. Concluíram que nos últimos 30 anos aumentaram os casos de câncer de orofaringe relacionados ao HPV de 16,3 a $71,7 \%$, por isso é importante o rastreamento da populacão em geral, com oroscopia e laringoscopia e o encaminhamento imediato ao especialista se houver alguma lesão pré maligna. Outra medida de prevenção possível seria a vacinação.

Mehanna et al. (2013), fizeram uma meta-análise e uma revisão sistemática de 269 artigos, em um total de 19.368 pacientes com câncer de cabeça e pescoço, divididos em câncer de orofaringe e não-orofaringe, nos quais pesquisaram a prevalência do HPV, por localização geográfica, antes do ano 2000 e entre 2000 e 2004. A prevalência do câncer de orofaringe HPV positivo, na Europa, cresceu rapidamente em relação à da América do Norte de 40,5\% a 72,2\%. Esse aumento presente na última década, não seria o resultado de técnicas melhores de diagnóstico, pois a prevalência do HPV positivo em pacientes com tumores não orofaríngeos estabilizou-se, e em nível muito mais baixo, no mesmo período. Esse fato sugere que o HPV tem uma predileção pelos tumores de orofaringe e estes aparecem na faixa etária mais jovem e apresentam maiores taxas de sobrevida. Sugerem a vacinação para a prevenção, apesar do custo alto, rastreamento para a detecção de casos iniciais e educação sexual.

Quon et al., em 2013, analisaram a p16 em 48 pacientes com carcinoma de células escamosas de orofaringe tratados por cirurgia TORS(transoral robotic surgery) em relação ao controle loco regional, à sobrevida livre de doença e à sobrevida global. Concluíram que a presença do HPV positivo pelo p16, não influenciou no prognóstico, na recidiva nem na sobrevida livre de doença e na sobrevida global do paciente tratado por cirurgia TORS.

Dalianis (2014a e b), revisou a relação entre o HPV e o carcinoma de células escamosas de orofaringe, enfatizando ser melhor a sobrevida livre de doença em 5 anos 
quando os tumores apresentam o HPV, melhor em 5 anos, do que o observado em pacientes com tumores de cabeça e pescoço em geral, e também os carcinomas de orofaringe HPV negativos ( $80 \%$ versus 40\%). Com essa melhor evolução clínica, sugere ser o HPV, um marcador preditivo e prognóstico, e que o tratamento do carcinoma de células escamosas de orofaringe HPV positivos deveria ser revisto. O autor também sugeriu que o HPV possa estar nas duas formas, a episomal e a integrada no genoma do mesmo paciente. Referiu também o aumento nas últimas décadas do HPV associado ao câncer de orofaringe, entre os pacientes jovens, com maior atividade sexual, e o declínio do câncer de orofaringe não associado ao HPV, pela diminuição do tabagismo, na Suécia. Sugeriu que outros marcadores imunológicos, como o CD44, CD8, MHC classe I, contagem de TIL, que possam interagir com o HPV, tornando sua terapia mais eficaz.

Benson et al. (2014), também revisaram a relação entre o status HPV e os tumores de cabeça e pescoço. Observaram que os pacientes acometidos pelo HPV, além de serem mais jovens, são mais frequentemente brancos, com maior atividade sexual, também têm maior escolaridade. O estádio clínico dos tumores de orofaringe, HPV associados, são predominantemente mais avançados ao diagnóstico, mais devido à metástases linfonodais $(\mathrm{N})$ do que à extenão do tumor primário $(\mathrm{T})$. Outrassim eles tem uma resposta favorável ao tratamento, com melhor sobrevida global e livre de doença, e controle loco regional melhor que os HPV negativos, porém existe maior risco de metástases à distância (M). Concluem, que até este momento a desintensificação do tratamento só deveria ser realizada em estudos randomizados.

Ljøkjel et al., 2014, em um estudo sobre o impacto da infecção pelo HPV, em pacientes portadores de câncer de orofaringe tratados na Noruega, revelaram ser a idade e o tabagismo, os fatores que significativamente interferiam nas taxas de sobrevida livre 
de doença, em pacientes com tumores HPV positivos. Assim quanto menor a idade e menor ou ausente o hábito de fumar, melhor a taxa de sobrevida livre de doença. Contudo, em paciente com tumores HPV negativos, o maior fator de influência continuava sendo o estádio clínico. Enfatizaram ainda que os pacientes submetidos a tratamento cirúrgico, independente do status HPV, também apresentavam taxas de sobrevida livre de doença melhores.

Tertipis et al., em 2015 propuseram um modelo de predição positivo para a desintensificação do tratamento do câncer de amígadala e base de língua, combinando marcadores moleculares e características clínicas e demográficas. Assim, estudaram retrospectivamente, a presença do HLA-I, o CD44 e o CD8+ TIL, em relação à idade, estádio clínico, tabagismo, tratamento e sobrevida livre de doença em 3 anos, em 197 pacientes HPV positivos, detectados por PCR. Ao validar o estudo encontraram que a ausência de expressão de HLA-1, a expressão de CD8+ TIL, idade mais jovem e estadiamento precoce, são preditores positivos de um tratamento adequado e consequente sobrevida melhor em 3 anos. Esta população com estas características poderá ser num futuro candidata a desintensificação do tratamento.

Hauck et al., (2015), salientaram haver diferenças geográficas na prevalência do HPV. Assim existiriam países dessenvolvidos com alta prevalência (até 80\%) como Estados Unidos, Canadá e Suécia, e média prevalência (34\%), como a Alemanha. Em países em desenvolvimento como o Brasil, onde ainda há grande influência do tabagismo e etilismo como fator etiológico do câncer de cabeça e pescoço, a prevalência do HPV é baixa.

Whang et al., revisaram em 2015, os recentes progressos terapêuticos e estratégias para a prevenção e tratamento do câncer de cabeca e pescoço HPV associado. Em relação ao tratamento cirúrgico, destacaram a cirurgia transoral (TORS). 
Esta modalidade tem sido cada vez mais utilizada em tumores em estádio precoce (I e II), mas também em casos selecionados com doença em estádio localmente avançado (III e IV). Seja a técnica de tratamento cirúrgico transoral endoscópica, com laser ou robótica, as vantagens são menor morbidade e consequente menor tempo de internação, maior amplitude da ressecção e maior segurança. Destacaram também que com a quimioterapia adjuvante com cisplatina, pode-se obter ótimas taxas de resposta em câncer HPV associado, com até 90\% de taxa de sobrevida em 3 anos. Ela poderá ser substituida pelo cetuximab, por ser menos tóxico. A opção da radioterapia deve ser por técnica de intensidade modulada (IMRT) ao invés da radioterapia convencional, pois além de poupar os tecidos sãos, diminui a morbidade, o risco de acidente vascular cerebral por oclusão carotídea, a fibrose cervical, a xerostomia, a disfagia, a mucosite e o linfedema. Com essa finalidade ainda existem em andamento os protocolos que estudam a diminuição da dose e do tempo de duração da radioterapia. Quanto as terapias alvo, moleculares, ainda em estudo, são terapias direcionadas diretamente às oncoproteínas E6 e E7, impedindo-as de se ligarem à p53 e à pRb. E por fim além das vacinas profiláticas que previnem o contato com o HPV. Relatam existir também em estudo as vacinas terapêuticas que poderiam ser empregadas tratamento de tumores de cabeça e pescoço HPV associados.

Campbell et al., em 2015, estudaram o padrão de persistência do HPV16 na mucosa oral em homens saudáveis, de 18 a 70 anos, do Brasil, México e Estados Unidos, sem história prévia de câncer anogenital, nem verrugas nessa região. O seguimento foi feito por 4 anos e consistia em exame clínico e coleta de material genital e oral, a cada seis meses. Os 23 pacientes, nos quais havia o HPV 16, na mucosa oral no momento do estudo, eram predominantemente brancos, jovens, não hispânicos e não fumantes. Destes 43,5\% já apresentavam infecção prevalente pelo HPV16, e 56,5\% de 
infecção adquirida posteriormente o estudo. A persistência do HPV16 foi significantemente maior nos casos prevalentes, se mantendo em até $40 \%$ em 4 anos. A persistência nos casos incidentes se deu em apenas 10\%, em 30 meses. A importância do estudo é a separação entre os casos prevalentes e incidentes e mostrando a persistência do HPV16 nos casos prevalentes de $40 \%$ por 4 anos, pode estar relacionada com a oncogênese do câncer de orofaringe e sugerir assim uma prevenção ativa nessa população. 


\section{MÉTODOS}

\subsection{Delineamento do estudo}

Este foi um estudo transversal aninhado à uma coorte de pacientes portadores de carcinoma de células escamosas de orofaringe, com coleta retrospectiva de dados.

\subsection{População de estudo}

Foram analisados todos os pacientes submetidos à cirurgia, no período de 1984 a 2012, portadores de carcinoma de células escamosas de orofaringe, no AC Camargo Cancer Center. Dos 173 pacientes, 36 foram excluídos por não possuir blocos de parafina para o estudo; Trinta e um foram excluídos por não apresentar material adequado para a pesquisa do HPV e 20 foram excluídos por entrar nos critérios de exclusão ou estar com o estadiamento inadequado. Os oitenta e seis restantes foram estadiados de acordo com a classificação TNM, sétima edição, da International Union Against Cancer. Os critérios de exclusão foram: paciente ter sido submetido a algum tratamento prévio por câncer de outra localização, outros tipos histológicos e presença de metástases à distância.

\subsection{Coleta de dados}

A partir da revisão dos prontuários, foram coletadas informações demográficas, clínicas, terapêutica, dados anatomopatológicos e de seguimento (Anexo A).

\subsection{Pesquisa do HPV}

Os blocos de parafina foram recuperados no arquivo do Departamento de Anatomia Patológica do AC Camargo Cancer Center. A extração do DNA, diagnóstico viral e genotipagem, foram realizados no Laboratório de Inovação em Câncer, 
Departamento de Radiologia e Oncologia da Faculdade de Medicina da Universidade de São Paulo, LIM 24. Processo FAPESP 2008/57889-1.

\subsubsection{Extração de DNA}

Tecidos embebidos em parafina foram raspados manualmente de lâminas não coradas utilizando um bisturi estéril. Os flocos de parafina contendo o tecido foram colocadas em tubos de microcentrífuga de $1,5 \mathrm{ml}$ e a desparafinização foi realizada com a adição de $750 \mu 1$ de xileno, agitação em vortex, e centrifugação a $12.000 \mathrm{rpm}$ por 15 minutos, duas vezes. Os pellets de tecido foram lavados duas vezes, com etanol 100\% e $50 \%$ e secos brevemente a $37^{\circ} \mathrm{C}$ em bloco térmico. Os tecidos foram digeridos com $300 \mu 1$ de uma solução $0,1 \%$ de proteinase $\mathrm{K}$ (Tris $10 \mathrm{mM}$ pH 9,0, EDTA 2,5 mM, NaCl 62,5 mM, 1\% de SDS) (Proteinase K - Fungal, >20 units/mg, ThermoFisher Scientific, USA) por pelo menos 8 horas a $55^{\circ} \mathrm{C}$, sob agitação. Os tecidos totalmente lisados foram submetidos à extração com fenol-clorofórmio, adicionando um volume igual de UltraPure ${ }^{\mathrm{TM}}$ Phenol:Chloroform:Isoamyl Alcohol (25:24:1, volume a volume) (ThermoFisher Scientific, USA), vortexando, e centrifugando a $12.000 \mathrm{rpm}$ por 15

minutos. A fase aquosa foi transferida para um novo tubo e o DNA foi precipitado durante duas horas a $-70^{\circ} \mathrm{C}$, utilizando acetato de amónio 2,5M e 2,5 volumes de etanol $100 \%$ gelado. Os tubos foram centrifugados a $12.000 \mathrm{rpm}$ por 15 minutos a $4^{\circ} \mathrm{C}$, o sobrenadante foi descartado e os sedimentos foram lavados duas vezes com $1 \mathrm{ml}$ de etanol $70 \%$ gelado. Os pellets foram brevemente secos a $37^{\circ} \mathrm{C}$ em bloco térmico e ressuspendidos em água destilada e deionizada. A quantificação do DNA foi realizada utilizando o espectrofotómetro NanoDrop 2000 (ThermoFisher Scientific, USA).

\subsubsection{Genotipagem do HPV}

Os DNAs foram submetidos a genotipagem de HPV automatizada utilizando os kits INNO-LiPA HPV Genotyping Extra Amp kit (Fujirebio, USA), INNO-LiPA HPV 
Genotyping Extra kit (Fujirebio, USA) e o equipamento AutoBlot-3000H (MedTec Biolab Equipment, USA). Resumidamente, parte da região L1 do genoma do HPV foi amplificada por PCR utilizando iniciadores SPF10, assim como o gene humano HLADPB1, como controle de qualidade das amostras. Duzentos nanogramas de DNA foram utilizados como molde numa reação de $50 \mu 1$. A ciclagem utilizada foi: $37^{\circ} \mathrm{C}$ por 10 minutos, $94^{\circ} \mathrm{C}$ por 9 minutos, 40 vezes a $94^{\circ} \mathrm{C}$ por 30 segundos, $52^{\circ} \mathrm{C}$ por 45 segundos, $72^{\circ} \mathrm{C}$ por 45 segundos, e $72^{\circ} \mathrm{C}$ por 30 minutos. Dez microlitros dos produtos amplificados biotinilados resultantes foram então desnaturadas com $10 \mu 1$ de solução de desnaturação por 10minutos à temperatura ambiente e hibridizados durante uma hora a exatamente $49^{\circ} \mathrm{C}$ sob agitação, com sondas oligonucleotídicas capazes de identificar 28 tipos diferentes de HPV, imobilizadas em tiras de membranas. Após a hibridização, foram realizadas três lavagens estringentes a exatamente $49^{\circ} \mathrm{C}$, sob agitação, duas por 1minuto e a última por 30 minutos. A seguir, foram realizados dois ciclos de lavagem por 1minuto, sob agitação à temperatura ambiente e, em seguida, foi adicionada fosfatase alcalina conjugada com estreptavidina e mantida por 30 minutos sob agitação à temperatura ambiente. Novamente, dois ciclos de lavagem foram realizados e após 30minutos de incubação com o tampão do substrato, sob agitação à temperatura ambiente, as tiras de membrana foram finalmente incubadas com o substrato BCIP/NBT por 30 minutos sob agitação à temperatura ambiente, terminando com mais dois ciclos de enxague. As tiras foram secas por pelo menos 8 horas à temperatura ambiente e, em seguida, as linhas visíveis foram identificadas usando o INNO-LiPA HPV Genotyping Extra Reading Card e interpretadas de acordo com o INNO-LiPA HPV Genotyping Extra Interpretation Chart. 


\subsection{Variáveis do estudo:}

As características demográficas estudadas foram sexo, idade e raça, e as de estilo de vida foram o tabagismo e o etilismo.

As características clínicas foram o tempo de sintomas, o tipo de sintoma, o local da orofaringe acometido, o estadiamento clínico, a recidiva e seu local, e o status do seguimento.

As características da terapêutica foram o tipo de cirurgia, o tipo de esvaziamento cervical ipsilateral e contralateral, a reconstrução, a ocorrência de complicação e o tempo de internação.

As características anatomopatológicas estudadas foram o grau histológico de diferenciação tumoral, a presença de margens livres, a ocorrência de invasão perineural, a ocorrência de embolização vascular e a presença de linfonodos acometidos.

Foram coletados dados do seguimento como ocorrência de recorrências e sua localização. Foi calculado o tempo de sobrevida livre de doença, como a diferença entre a data da cirurgia e a data da recidiva ou a data da última informação objetiva de seguimento. Foi calculado também o tempo de sobrevida global, como a diferença entre a data da cirurgia e a data do óbito ou da última informação objetiva de seguimento. $\mathrm{O}$ tempo de seguimento nas duas análises foi censurado em 60 meses.

\subsection{Análise estatística}

A descrição da amostra foi realizada através de média, frequências absoluta e relativa.

Foi estimada a prevalência do HPV e seu respectivo intervalo de 95\% de confiança.

A análise da associação entre a presença de HPV e as características demográficas, clínicas e patológicas, foi feita pelo teste de associação pelo quiquadrado, considerando-se significativos valores de $\mathrm{p}<0,05$.

A análise da sobrevida livre de doença e sobrevida global foi feita pelo estimador produto limite de Kaplan-Meier. A significância estatística entre as diferentes 
categorias de uma mesma variável foram estabelecidas pelo valor do teste de log-rank obtido, considerando-se significantes os valores de $\mathrm{p}<0,05$. Finalmente, a análise multivariada foi realizada utilizando-se o modelo de riscos proporcionais de Cox.

\subsection{Questões éticas}

Esse estudo foi submetido ao Comitê de Ética Médica do AC Camargo Cancer Center, instituição coparticipante, CAAE 00597812.1.0000.0065, na plataforma Brasil, sendo aprovado em 03/09/2013. 


\section{RESULTADOS}

\subsection{Caracterização da amostra:}

Foram analisados 86 pacientes com idade variando de 34 a 78 anos (média de 56,9 anos), sendo mais frequente na sexta e sétima décadas de vida. A maioria dos pacientes eram brancos $(83,7 \%)$, homens $(88,4 \%)$, fumantes $(69,8 \%)$ e etilistas $(71,4 \%)$. (Tabela 1)

Tabela 1. Número e porcentagem de pacientes com carcinoma de células escamosas de orofaringe tratados por cirurgia, segundo características demográficas e estilo de vida. AC Camargo Cancer Center 1984-2012

\begin{tabular}{lllc}
\hline variável & categoria & número & \% \\
\hline sexo & masculino & 76 & 88,4 \\
& feminino & 10 & 11,6 \\
idade & $<55$ anos & 40 & 46,5 \\
& $\geq 55$ anos & 46 & 53,5 \\
raça & branca & 72 & 83,7 \\
& não branca & 12 & 14,0 \\
tabagismo & ignorada & 2 & 2,3 \\
& sim & 65 & 75,6 \\
& não & 06 & 7,0 \\
Total & ignorado & 15 & 17,4 \\
& sim & 54 & 62,8 \\
\hline & não & 16 & 18,6 \\
& ignorado & $\mathbf{8 6}$ & $\mathbf{1 0 0 , 0}$ \\
\hline
\end{tabular}


A maioria dos pacientes $(69,0 \%)$ apresentou início dos sintomas até seis meses antes da admissão para tratamento. O sintoma mais comum foi a odinofagia isolada $(38,4 \%)$ ou acompanhada de nódulo cervical (61,6\%). A amígdala $(69,8 \%)$ foi a localização mais frequente. (Tabela 2).

Tabela 2. Número e porcentagem de pacientes com carcinoma de células escamosas de orofaringe tratados por cirurgia, segundo características clínicas. AC Camargo Cancer Center 1984-2012

\begin{tabular}{llll}
\hline variável & categoria & número & \% \\
\hline tempo de sintoma & 6 meses & 61 & 69,0 \\
& $>6$ meses & 16 & 20,5 \\
& ignorado & 9 & 10,5 \\
\multirow{2}{*}{ sintoma+frequente } & odinofagia & 33 & 38,4 \\
& odinofagia+nódulo & 53 & 61,6 \\
localização & amígdala & 60 & 69,8 \\
& outros & 26 & 30,2 \\
Total & & $\mathbf{8 6}$ & $\mathbf{1 0 0 , 0}$ \\
\hline
\end{tabular}

O estadiamento clínico com maior representatividade foi o III e IV $(71,4 \%)$. O $\mathrm{T}$ com maior número foi o $\mathrm{T} 3$ com 36 pacientes $(41,9 \%)$ e o $\mathrm{N}$ foi o $\mathrm{N} 0$, com 31 pacientes $(36 \%)$.

Foram realizadas cirurgias amplas como bucofaringectomias em 76 pacientes $(88,4 \%)$, as outras foram as endorais em $10(11,6 \%)$. Para o tratamento do pescoço ipsilateral foi realizado o esvaziamento cervical em 81 pacientes $(94,2 \%)$, sendo o radical clássico em $35(54,8 \%)$ e o modificado em 30 pacientes $(32,6 \%)$. O pescoço contralateral foi tratado com esvaziamento em 21 pacientes $(24,4 \%)$. A reconstrução cirúrgica foi realizada em 70 pacientes $(81,4 \%)$, desde fechamento local em 27 pacientes $(31,4 \%)$, retalho miocutâneo em 28 (32,6\%) e retalho microcirúrgico em 14 (16,3\%). As complicações observadas em 47 pacientes $(54,7 \%)$, foram locais como deiscência $(10,5 \%)$ e infecção local $(7,0 \%)$, e gerais como broncopneumonia $(4,7 \%)$. O tempo de internação variou de um a trinta dias (média de 10 dias). (Tabela 3) 
Tabela 3. Número e porcentagem dos pacientes com carcinoma de células escamosas de orofaringe tratados por cirurgia segundo características círúrgicas. AC Camargo Cancer Center 1984-2012

\begin{tabular}{llcc}
\hline variavel & categoria & $\mathrm{n}^{0}$ & $\%$ \\
\hline tipo de cirurgia & endoral & 10 & 11,6 \\
& não endoral & 76 & 88,4 \\
esvaziamento & sim & 81 & 94,2 \\
cervical ipsilateral & não & 5 & 5,8 \\
esvaziamento & sim & 21 & 24,4 \\
cervical & não & 65 & 75,6 \\
recontralateral & simstrução & 70 & 84,3 \\
& não & 16 & 15,7 \\
complicação & sim & 47 & 54,7 \\
& não & 39 & 45,3 \\
\hline Total & & $\mathbf{8 6}$ & $\mathbf{1 0 0 , 0}$ \\
\hline
\end{tabular}

A maioria dos pacientes $74(86 \%)$ foi submetido a radioterapia adjuvante, recebendo doses que variavam de 4400 a 7000 cGy no tumor primário e de 4500 a 7040cGy na região de drenagem cervical (uni ou bilateral).

No exame anatomo patológico foi encontrado carcinoma de células escamosas grau II em 37 pacientes (43\%). Margens livres foram observadas em 64 casos $(75,3 \%)$. Não se observou invasão perineural em 55 tumores (64\%). A embolização linfática apresentou-se em 27 casos (31,4\%) e a embolização vascular em apenas 12 (14\%). Os linfonodos estavam comprometidos do lado ipsilateral em 62 casos $(72,1 \%)$ e o local mais acometido, o nível II, com 19 casos (22,1\%). Os linfonodos estavam comprometidos do lado contralateral em apenas 10 casos $(11,6 \%)$ e o local mais acometido foi o nível II com 6 casos (7\%). (Tabelas 4 e 5 ) 
Tabela 4. Número e porcentagem dos pacientes com carcinoma de células escamosas de orofaringe tratados por cirurgia, segundo caracterização do anátomo patológico. AC Camargo Cancer Center 1984-2012

\begin{tabular}{lllc}
\hline variável & categoria & número & $\%$ \\
\hline $\begin{array}{l}\text { grau histológico } \\
\text { diferenciação } \\
\text { tumoral }\end{array}$ & I & 32 & 37,1 \\
& II & 37 & 43,0 \\
& III & 14 & 16,3 \\
& in situ & 1 & 1,2 \\
margens livres & basalóide & 1 & 1,2 \\
& livres & 64 & 1,2 \\
invasão perineural & comprometidas & 12 & 75,3 \\
& sim & 31 & 24,7 \\
embolização & não & 55 & 36,0 \\
vascular & sim & 12 & 64,0 \\
& não & 66 & 14,0 \\
Total & ignorado & 8 & 76,7 \\
\hline
\end{tabular}

Tabela 5. Número e porcentagem dos pacientes com carcinoma de células escamosas de orofaringe tratados por cirurgia, segundo caracterização do anátomo patológico. AC Camargo Cancer Center 1984-2012

\begin{tabular}{llll}
\hline variável & categoria & número & \% \\
\hline linfonodo ipsilateral & sim & 62 & 72,1 \\
& não & 24 & 27,9 \\
linfonodo & sim & 10 & 11,6 \\
contralateral & não & 76 & 88,4 \\
Total & & $\mathbf{8 6}$ & $\mathbf{1 0 0 , 0}$ \\
\hline
\end{tabular}




\subsection{Análise da associação com o HPV}

A prevalência de achado positivo para HPV foi de 57\% $(\mathrm{IC}=[46,5 ; 67,5])$. O tipo mais comum foi o 16 em 41 casos $(83,6 \%)$, seguido do tipo 18 com 6 casos $(12,2 \%)$, e do 26 com 3 casos $(6,1 \%)$. O tipo 33 e o 45 foram representados por um caso cada. Dois pacientes apresentaram associação dos tipos 18 e 26, sendo que um deles ainda apresentava o 16 associado. Figura 1 (Anexo B)

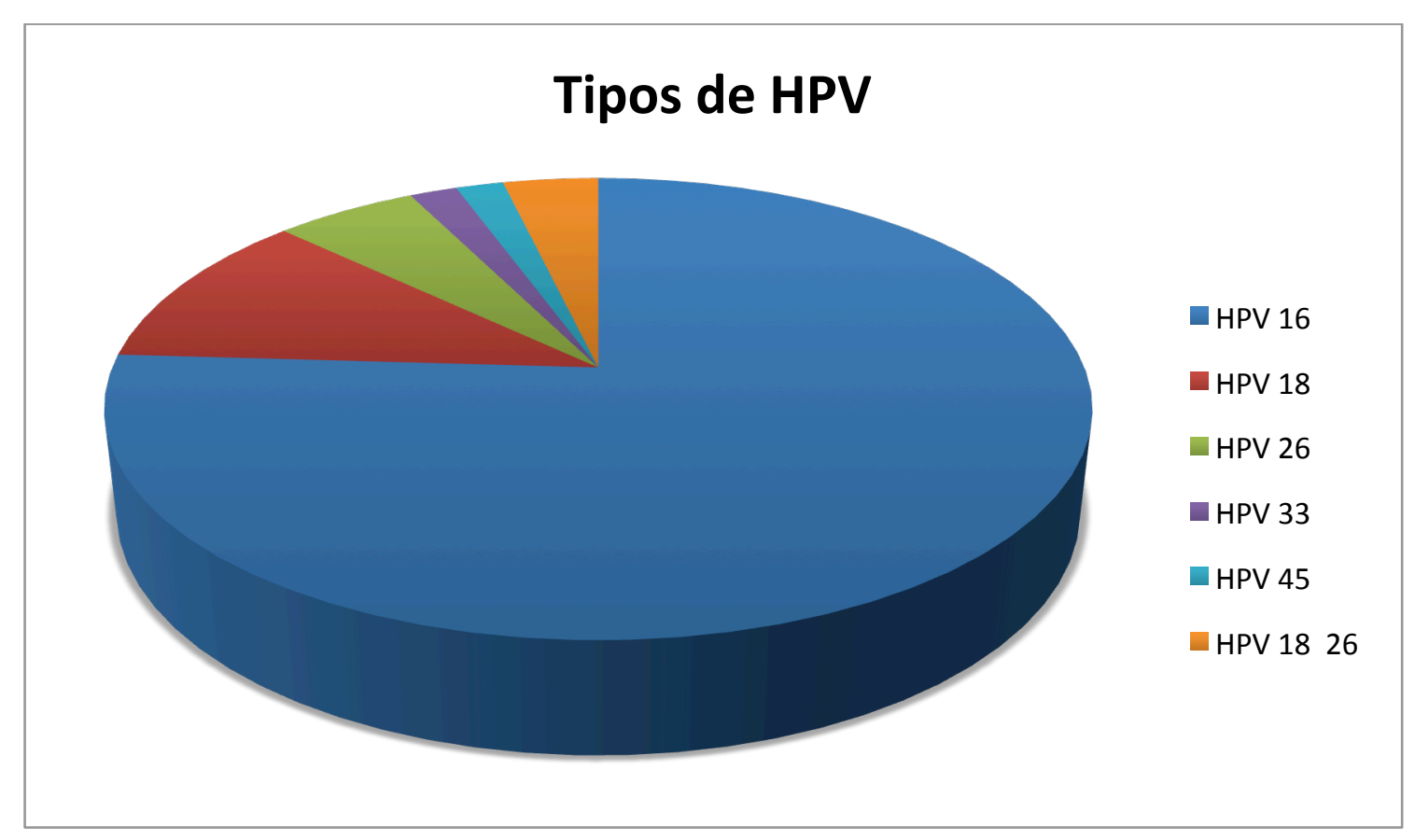

Figura 1. Relaciona os tipos de HPV encontrados nos pacientes portadores de carcinoma de células escamosas de orofaringe tratados por cirurgia. AC Camargo Cancer Center 1984-2012.

A Tabela 6 apresenta a análise das variáveis do estudo com a associação com o HPV. Observa-se que a única associação estatisticamente significativa foi com o tabagismo, onde todos os não fumantes tinham HPV contra 53,8\% nos fumantes/exfumantes $(p=0,027)$. 
Tabela 6. Número e porcentagem dos pacientes com carcinoma de células escamosas de orofaringe tratados por cirurgia, segundo as variáveis de estudo e presença do HPV. AC Camargo Cancer Center 1984-2012

\begin{tabular}{l|l|rr|r|l}
\hline variável & categoria & \multicolumn{2}{|c|}{ HPV } & total & p \\
& & não & sim & & \\
\hline sexo & masculino & $\begin{array}{l}35(46,1) \\
\text { o }\end{array}$ & $41(53,9)$ & $76(100,0)$ & 0,118 \\
& feminino & $2(20,0)$ & $8(80,0)$ & $10(100,0)$ & \\
\hline idade & até 55anos & $21(52,5)$ & $19(47,5)$ & $40(100,0)$ & 0,098 \\
& $\geq 55$ anos & $16(34,8)$ & $30(65,2)$ & $46(100,0)$ & \\
\hline raça & branca & $34(45,8)$ & $40(54,2)$ & $74(100,0)$ & 0,177 \\
& não branca & $3(25,0)$ & $9(75,0)$ & $12(100,0)$ & \\
\hline tabagismo & sim & $37(46,2)$ & $43(53,8)$ & $80(100,0)$ & 0,027 \\
& não & $0(0,0)$ & $6(100,0)$ & $6(100,0)$ & \\
\hline etilismo & sim & $24(48,0)$ & $26(52,0)$ & $50(100,0)$ & 0,488 \\
& não & $5(31,2)$ & $11(68,8)$ & $16(100,0)$ & \\
& ex-etilista & $2(50,0)$ & $2(50,0)$ & $4(100,0)$ & \\
& ignorado & $6(37,5)$ & $10(62,5)$ & $16(100,0)$ & \\
\hline estádio & I+II & $11(45,8)$ & $14(54,2)$ & $25(100,0)$ & 0,835 \\
clínico & III+IV & $26(43,3)$ & $35(56,7)$ & $61(100,0)$ & \\
\hline tumor & T1+T2 & $11(45,8)$ & $14(54,2)$ & $25(100,0)$ & 0,835 \\
& T3+T4 & $26(43,3)$ & $35(56,7)$ & $61(100,0)$ & \\
\hline linfonodo & N0+N1 & $25(52,1)$ & $23(47,9)$ & $48(100,0)$ & 0,087 \\
& N2+N3 & $12(33,3)$ & $26(66,7)$ & $38(100,0)$ & \\
\hline Total & & $\mathbf{3 7 ( 4 3 , 0 )}$ & $\mathbf{4 9 ( 5 7 , 0 )}$ & $\mathbf{8 6 ( 1 0 0 , 0 )}$ & \\
\hline
\end{tabular}

- teste log-rank

A tabela 7 associa as características dos achados do exame anátomo patológico da peça cirúrgica com o estudo do HPV. Nenhuma delas foi estatisticamente significativa. 
Tabela 7. Associação de características dos achados do exame anátomo patológico da peça cirurgica com o resultado do estudo do HPV. AC Camargo Cancer Center 1984-2012

\begin{tabular}{|c|c|c|c|c|c|c|}
\hline \multirow[t]{3}{*}{ variável } & \multirow[t]{3}{*}{ categoria } & \multicolumn{4}{|c|}{ HPV } & \multirow[t]{3}{*}{$\mathrm{p}^{*}$} \\
\hline & & \multicolumn{2}{|c|}{ não } & \multicolumn{2}{|c|}{ sim } & \\
\hline & & $\mathrm{n}$ & $\%$ & & $\%$ & \\
\hline margens & $\begin{array}{l}\text { não comprometida } \\
\text { comprometida }\end{array}$ & $\begin{array}{l}25 \\
12\end{array}$ & $\begin{array}{l}39,1 \\
57,1\end{array}$ & $\begin{array}{c}39 \\
9\end{array}$ & $\begin{array}{l}60,9 \\
42,9\end{array}$ & 0,147 \\
\hline $\begin{array}{l}\text { grau } \\
\text { histológico de } \\
\text { diferenciação }\end{array}$ & $\begin{array}{l}\text { in situ + I + II } \\
\text { III + IV + basalóide }\end{array}$ & $\begin{array}{r}32 \\
5\end{array}$ & $\begin{array}{l}45,7 \\
31,2\end{array}$ & $\begin{array}{l}38 \\
11\end{array}$ & $\begin{array}{l}54,3 \\
68,8\end{array}$ & 0,292 \\
\hline $\begin{array}{l}\text { embolização } \\
\text { vascular }\end{array}$ & $\begin{array}{l}\text { não } \\
\text { sim }\end{array}$ & $\begin{array}{c}27 \\
6\end{array}$ & $\begin{array}{l}40,9 \\
50,0\end{array}$ & $\begin{array}{c}39 \\
6\end{array}$ & $\begin{array}{l}59,1 \\
50,0\end{array}$ & 0,558 \\
\hline invasão neural & $\begin{array}{l}\text { não } \\
\text { sim }\end{array}$ & $\begin{array}{l}21 \\
13 \\
\end{array}$ & $\begin{array}{l}42,9 \\
41,9 \\
\end{array}$ & $\begin{array}{l}28 \\
18 \\
\end{array}$ & $\begin{array}{l}57,1 \\
58,1 \\
\end{array}$ & 0,935 \\
\hline $\begin{array}{l}\text { linfonodos } \\
\text { ipsilaterais }\end{array}$ & $\begin{array}{l}\text { não } \\
\text { sim }\end{array}$ & $\begin{array}{l}9 \\
28\end{array}$ & $\begin{array}{l}37,5 \\
45,2 \\
\end{array}$ & $\begin{array}{l}15 \\
34 \\
\end{array}$ & $\begin{array}{l}62,5 \\
54,8\end{array}$ & 0,520 \\
\hline $\begin{array}{l}\text { linfonodos } \\
\text { contralaterais }\end{array}$ & $\begin{array}{l}\text { não } \\
\text { sim }\end{array}$ & $\begin{array}{r}32 \\
5 \\
\end{array}$ & $\begin{array}{l}42,1 \\
50,0 \\
\end{array}$ & $\begin{array}{r}44 \\
5 \\
\end{array}$ & $\begin{array}{l}57,9 \\
50,0 \\
\end{array}$ & 0,635 \\
\hline \multicolumn{2}{|l|}{ Total } & 37 & $(43,0)$ & 49 & $(57,0)$ & \\
\hline
\end{tabular}

- teste log-rank

\subsection{Análise da sobrevida livre de doença.}

Dos 86 pacientes, 37 tiveram recidiva (43\%), e o local mais frequente foi o pescoço em 12 casos $(32,4 \%)$. A Tabela 8 apresenta os resultados da análise da sobrevida livre de doença. As taxas de sobrevida livre de doença foram de 73,9\%, $65,9 \%$ e 57,9\%, respectivamente aos 12,24 e 60 meses. Houve diferença estatisticamente significativa entre as curvas de sobrevida segundo a idade $(p=0,057)$ e a margem $(\mathrm{p}=0,014)$, com piores taxas de sobrevida para os pacientes com até 55 anos e com margens comprometidas. A presença do HPV não influenciou a sobrevida livre de doença $(\mathrm{p}=0,486)$. No modelo múltiplo de Cox, verificou-se que a idade até 55 anos $(\mathrm{HR}=2,6 ; \mathrm{p}=0,008)$ e o comprometimento de margens $(\mathrm{HR}=2,3 ; \mathrm{p}=0,026)$, são fatores 
de risco independentes para a sobrevida livre de doença de pacientes com carcinoma de células escamosas de orofaringe tratados por cirurgia.

Tabela 8. Análise da sobrevida livre de doença em relação às características demográficas, estilo de vida e patológicas. AC Camargo Cancer Center 1984-2012

\begin{tabular}{|c|c|c|c|c|c|}
\hline variável & categoria & sob & vida livre d & loença & $\mathbf{p}^{*}$ \\
\hline & & 12meses & 24meses & 60meses & \\
\hline & & $(\%)$ & $(\%)$ & $(\%)$ & \\
\hline sexo & masculino & 90,6 & 76,4 & 55,2 & 0,283 \\
\hline & feminino & 77,8 & 77,8 & 77,8 & \\
\hline idade & $<55$ anos & 66,7 & 55,6 & 46,9 & 0,057 \\
\hline & $\geq 55$ anos & 80,7 & 75,4 & 68,4 & \\
\hline HPV & $\operatorname{sim}$ & 77,7 & 63,9 & 61,5 & 0,486 \\
\hline & não & 75,1 & 60,9 & 51,6 & \\
\hline tabagismo & $\operatorname{sim}$ & 73,2 & 64,4 & 55,5 & 0,252 \\
\hline & não & 83,3 & 83,3 & 83,3 & \\
\hline etilismo & $\operatorname{sim}$ & 70,5 & 61,7 & 53,6 & 0,210 \\
\hline & não & 80,8 & 74,0 & 74,0 & \\
\hline estádio & $\mathrm{I}+\mathrm{II}$ & 76,9 & 72,1 & 55,6 & 0,939 \\
\hline & $\mathrm{III}+\mathrm{IV}$ & 71,9 & 62,2 & 57,4 & \\
\hline margem & positiva & 61,0 & 45,1 & 31,0 & 0,014 \\
\hline & negativa & 78,1 & 72,6 & 66,2 & \\
\hline Total & & 73,9 & 65,9 & 57,9 & \\
\hline
\end{tabular}

* teste log-rank 
A tabela 9 apresenta algumas interações analisadas entre tabagismo e etilismo, estádio clínico e a presença de HPV, com a sobrevida livre de doença. Nenhuma delas foi estatisticamente significativa.

Tabela 9. Interações entre tabagismo e etilismo, estádio clínico e a presença de HPV e sobrevida livre de doença. AC Camargo Cancer Center 1984-2012

\begin{tabular}{|c|c|c|c|c|c|}
\hline variável & categoria & $\begin{array}{l}\text { sobre } \\
12 \mathrm{me} \\
(\%)\end{array}$ & $\begin{array}{l}\text { la livr } \\
24 \mathrm{~m} \\
(\%)\end{array}$ & $\begin{array}{l}\text { doença } \\
\text { 60meses } \\
(\%)\end{array}$ & $\mathbf{p}^{*}$ \\
\hline $\begin{array}{l}\text { etilismo } \\
\text { estádio clínico }\end{array}$ & $\begin{array}{l}\text { não etilista } \\
\text { etilista + EC I/II } \\
\text { etilista + EC III/IV }\end{array}$ & $\begin{array}{l}80,8 \\
83,1 \\
67,0\end{array}$ & $\begin{array}{l}74,0 \\
73,8 \\
58,2\end{array}$ & $\begin{array}{l}74,0 \\
52,7 \\
54,6\end{array}$ & 0,440 \\
\hline etilismo X HPV & $\begin{array}{l}\text { não etilista } \\
\text { etilista sem HPV } \\
\text { etilista com HPV }\end{array}$ & $\begin{array}{l}80,8 \\
68,4 \\
72,5\end{array}$ & $\begin{array}{l}74,0 \\
68,4 \\
56,1\end{array}$ & $\begin{array}{l}74,0 \\
54,7 \\
51,2\end{array}$ & 0,447 \\
\hline $\begin{array}{l}\text { tabagismo } \mathrm{X} \\
\text { estádio clínico }\end{array}$ & $\begin{array}{l}\text { não tabagista } \\
\text { tabagista }+ \text { EC I/II } \\
\text { tabagista }+ \text { ECIII/IV }\end{array}$ & $\begin{array}{l}83,3 \\
74,5 \\
71,7\end{array}$ & $\begin{array}{l}83,3 \\
69,2 \\
61,1\end{array}$ & $\begin{array}{l}83,3 \\
50,4 \\
55,7\end{array}$ & 0,486 \\
\hline tabagismo X HPV & $\begin{array}{l}\text { não tabagista } \\
\text { tabagista sem HPV } \\
\text { tabagista com HPV }\end{array}$ & $\begin{array}{l}83,3 \\
69,0 \\
76,8\end{array}$ & $\begin{array}{l}83,3 \\
69,0 \\
60,8\end{array}$ & $\begin{array}{l}83,3 \\
51,6 \\
58,0\end{array}$ & 0,476 \\
\hline
\end{tabular}

*teste log-rank

\subsection{Análise da sobrevida global.}

Dos 86 pacientes, 49 tiveram óbito até os 60 meses. O seguimento médio foi de 35 meses. A Tabela 10 apresenta os resultados da análise da sobrevida global. As taxas de sobrevida global foram de 75,6\%, 54,7\% e 43,0\%, respectivamente aos 12 , 24 e 60 
meses. Houve diferença estatisticamente significativa entre as curvas de sobrevida global segundo etilismo $(\mathrm{p}=0,059)$, com piores taxas de sobrevida global os pacientes etilistas e com recidiva. A presença do HPV não influenciou a sobrevida global de doença $(p=0,363)$.

Tabela 10. Análise da sobrevida global AC Camargo Cancer Center 1984-2012

\begin{tabular}{l|l|l|l|l|l}
\hline variável & categoria & \multicolumn{3}{|c|}{ sobrevida global } & \multirow{2}{*}{ * } \\
& \multicolumn{1}{|c|}{ n } & 12meses & 24meses & 60meses & \\
\hline sexo & masculino & 71,1 & 53,9 & 40,7 & 0,404 \\
& feminino & 70,0 & 60,0 & 60,0 & \\
\hline idade & até 55anos & 72,5 & 57,5 & 42,5 & 0,806 \\
& $\geq 55$ anos & 69,6 & 52,2 & 43,5 & \\
\hline HPV & sim & 73,5 & 61,2 & 46,9 & 0,363 \\
& não & 67,6 & 45,9 & 37,6 & \\
\hline tabagismo & sim & 75,0 & 53,7 & 41,2 & 0,288 \\
& não & 83,3 & 66,7 & 66,7 & \\
\hline etilismo & sim & 68,5 & 46,3 & 31,5 & 0,059 \\
& não & 75,0 & 68,8 & 62,5 & \\
\hline estadiamento & I+II & 70,8 & 58,3 & 45,8 & 0,758 \\
& III+IV & 70,0 & 51,7 & 39,9 & \\
\hline margem & positiva & 71,4 & 46,7 & 28,6 & 0,267 \\
& negativa & 70,3 & 56,3 & 46,9 & \\
\hline
\end{tabular}

* teste log-rank

A tabela 11 apresenta algumas interações analisadas entre tabagismo e etilismo, estádio clínico e a presença de HPV, com a sobrevida global. Nenhuma delas foi estatisticamente significativa 
Tabela 11. Interações entre tabagismo e etilismo, estádio clínico e a presença de HPV e sobrevida global. AC Camargo Cancer Center 1984-2012

\begin{tabular}{|c|c|c|c|c|c|}
\hline variável & categoria & $\begin{array}{r}\mathrm{s} \\
12 \mathrm{me} \\
(\%)\end{array}$ & $\begin{array}{l}\text { cevida } \\
24 \mathrm{~m} \\
(\%)\end{array}$ & $\begin{array}{l}\text { bal } \\
\text { 60meses } \\
(\%)\end{array}$ & $\mathbf{p}^{*}$ \\
\hline $\begin{array}{l}\text { etilismo } \\
\text { estádio clínico }\end{array}$ & $\begin{array}{l}\text { não etilista } \\
\text { etilista + EC I/II } \\
\text { etilista + EC III/IV }\end{array}$ & $\begin{array}{l}75,0 \\
69,2 \\
68,3\end{array}$ & $\begin{array}{l}68,8 \\
46,2 \\
43,9\end{array}$ & $\begin{array}{l}62,5 \\
30,8 \\
31,7\end{array}$ & 0,167 \\
\hline etilismo X HPV & $\begin{array}{l}\text { não etilista } \\
\text { etilista sem HPV } \\
\text { etilista com HPV }\end{array}$ & $\begin{array}{l}75,0 \\
57,7 \\
67,9\end{array}$ & $\begin{array}{l}68,8 \\
34,6 \\
53,6\end{array}$ & $\begin{array}{l}62,5 \\
26,9 \\
39,3\end{array}$ & 0,137 \\
\hline $\begin{array}{l}\text { tabagismo } \mathrm{X} \\
\text { estádio clínico }\end{array}$ & $\begin{array}{l}\text { não tabagista } \\
\text { tabagista }+ \text { EC I/II } \\
\text { tabagista }+ \text { ECIII/IV }\end{array}$ & $\begin{array}{l}83,3 \\
68,2 \\
69,6\end{array}$ & $\begin{array}{l}66,7 \\
50,0 \\
51,8\end{array}$ & $\begin{array}{l}66,7 \\
40,9 \\
39,1\end{array}$ & 0,533 \\
\hline tabagismo X HPV & $\begin{array}{l}\text { não tabagista } \\
\text { tabagista sem HPV } \\
\text { tabagista com HPV }\end{array}$ & $\begin{array}{l}83,3 \\
73,0 \\
72,1\end{array}$ & $\begin{array}{l}66,7 \\
45,9 \\
60,5\end{array}$ & $\begin{array}{l}66,7 \\
37,6 \\
44,2\end{array}$ & 0,455 \\
\hline
\end{tabular}

*teste log-rank

$\mathrm{Na}$ figura 2, visualizamos que apesar da interação das variáveis sobre o etilismo e HPV não ter sido estatisticamente significativa, sugeriu-se que os pacientes não etilistas apresentaram a sobrevida global melhor, e a presença do HPV não exerceu influência na melhoria da sobrevida global. 


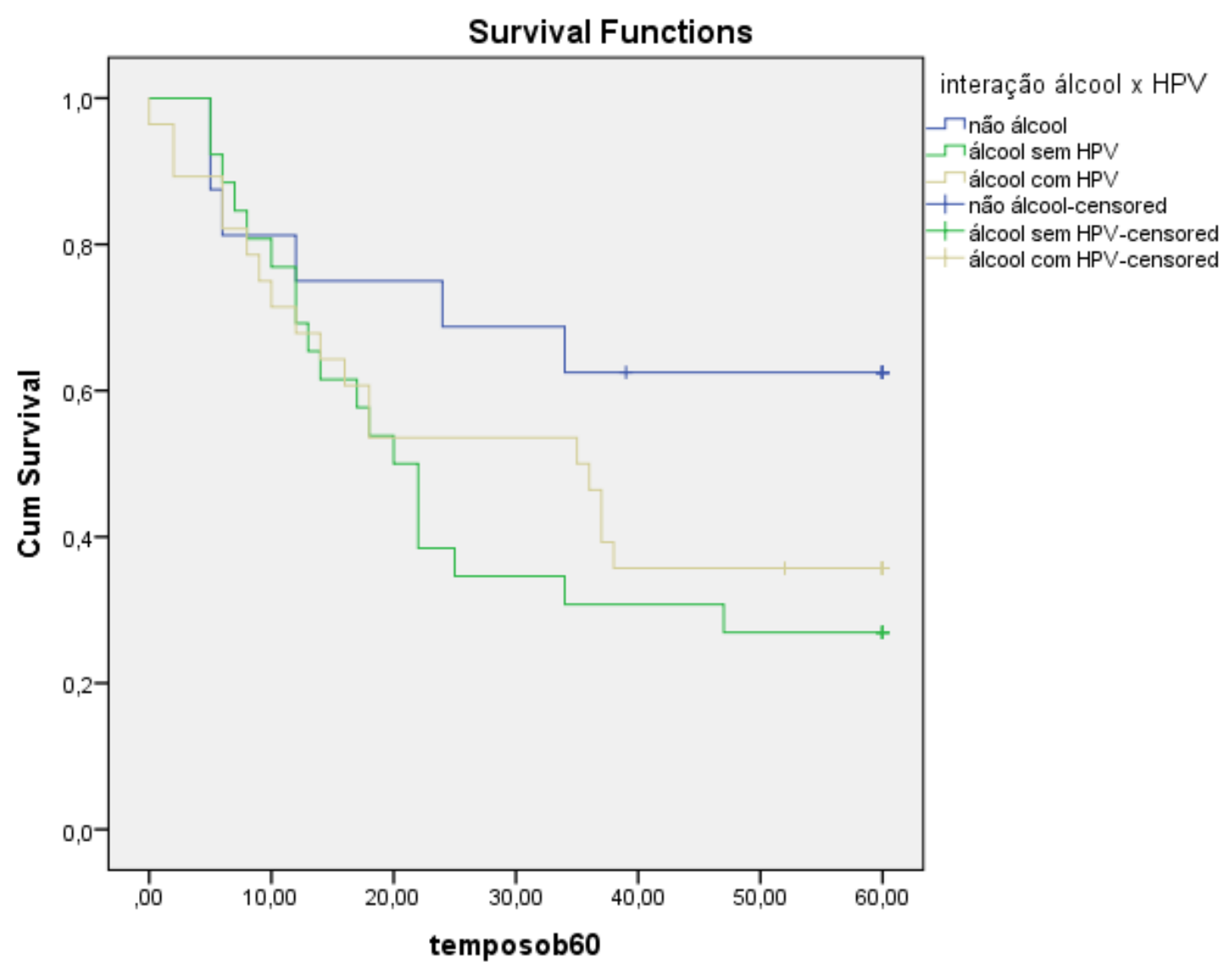

Fig. 2 Curva de sobrevida global, associando as variáveis etilismo e HPV. AC Camargo Cancer Center 1984-2012

Na figura 3, visualizamos que apesar da interação das variáveis sobre o etilismo e estádio clínico, também não foi estatisticamente significativa, sugeriu-se que os pacientes não etilistas apresentaram a sobrevida global melhor. 


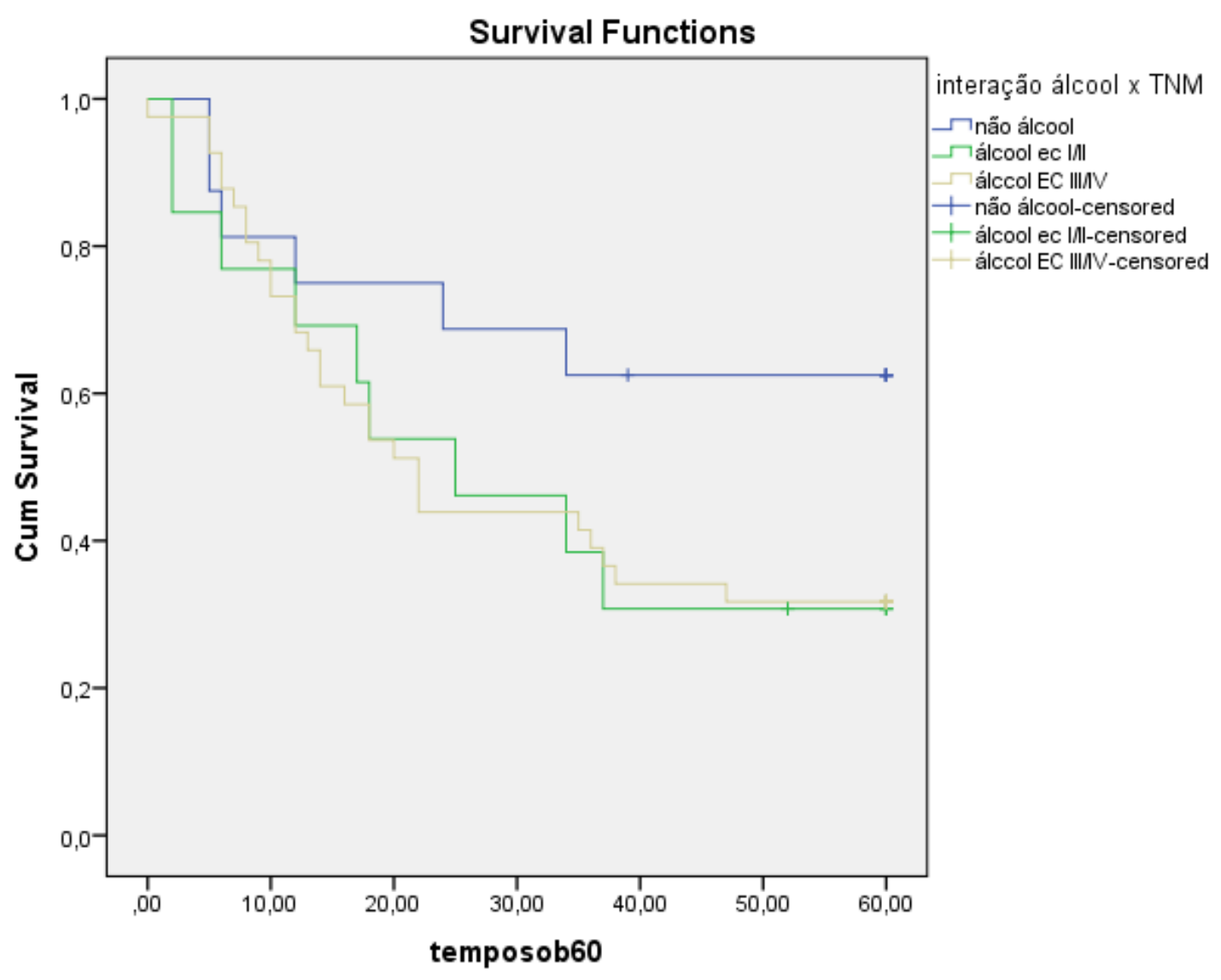

Fig. 3 Curva de sobrevida global, associando as variáveis etilismo e estádio clínico. AC Camargo Cancer Center 1984-2012

Ao visualizarmos na figura 4, a interação entre as variáveis etilismo e HPV, no estádio clínico precoce, analisamos que no paciente não etilista, houve uma sobrevida global melhor, porém sugeriu-se que o HPV não exerceu influência na sobrevida global. O valor de $\mathrm{p}=0,168$, não foi estatisticamente significativo. 


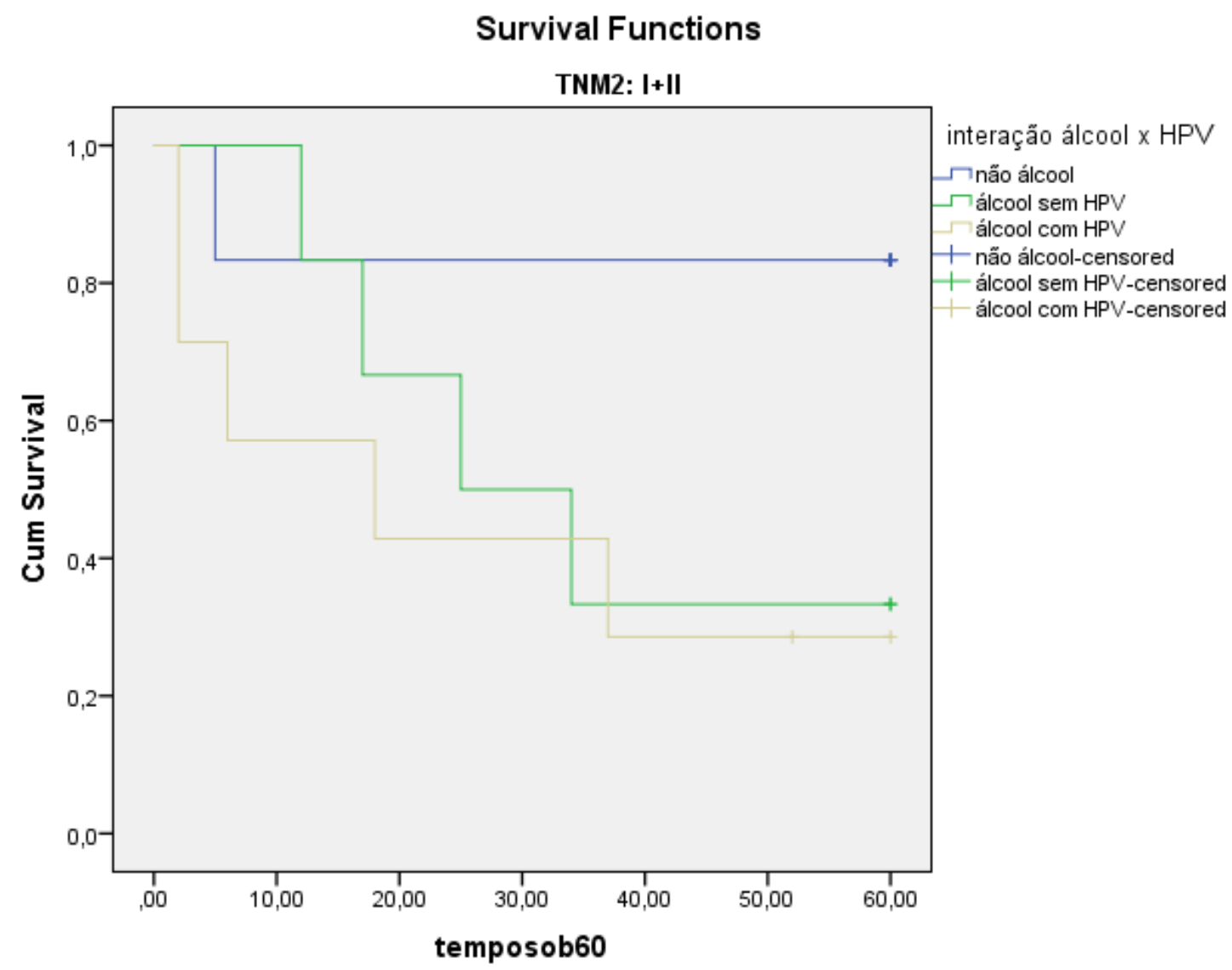

Fig. 4 Associação entre as variáveis etilismo e HPV, no estádio clínico precoce (I e II). AC Camargo Cancer Center 1984-2012.

Ao visualizarmos na figura 5, a associação entre as variáveis etilismo e HPV, no estádio clínico avançado, (III e IV), o paciente não etilista não apresentou sequer uma relativa melhora da sobrevida global. A presença do HPV revelou discreta melhora da sobrevida global porém não foi estatisticamente significativo $(p=0,384)$ 


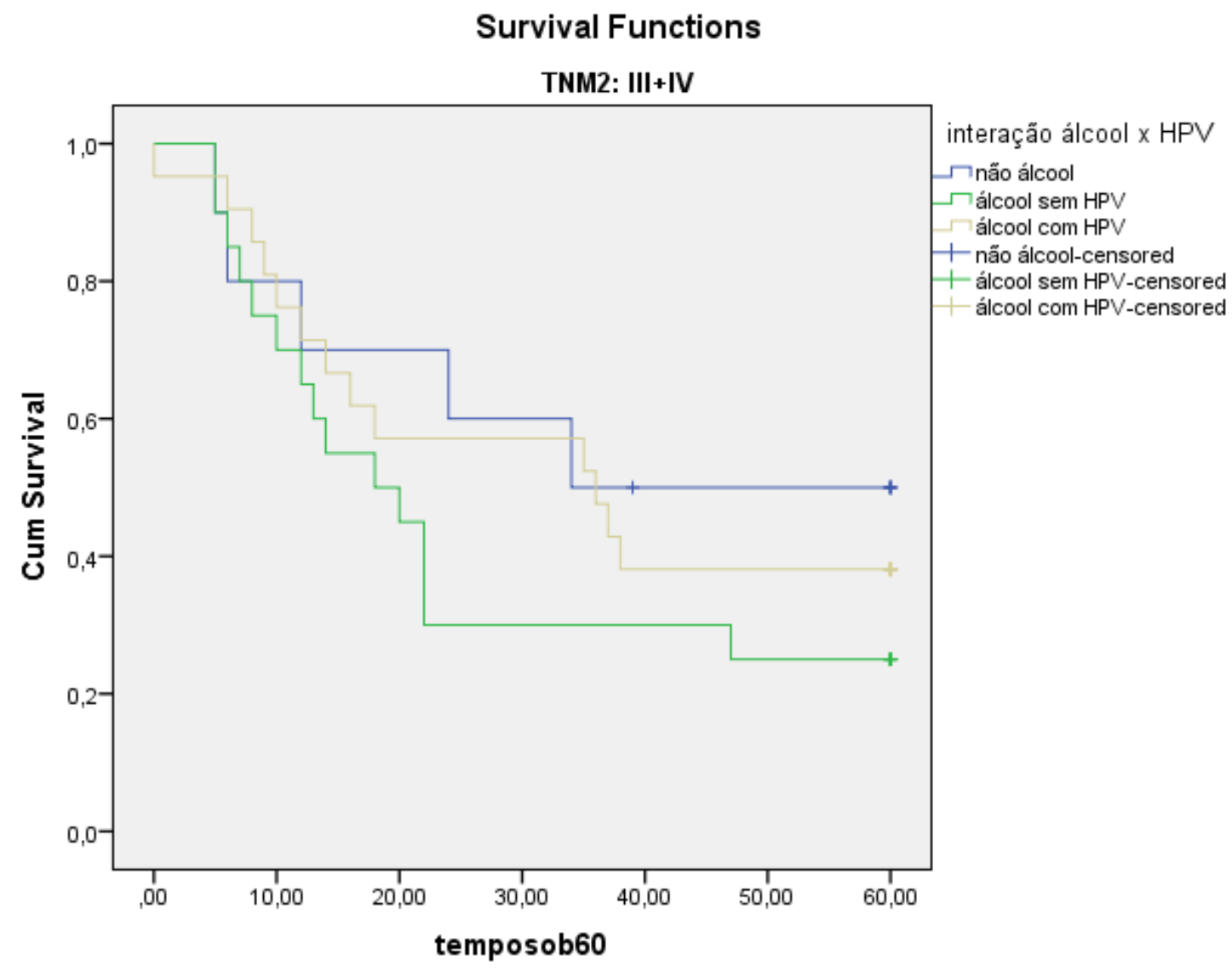

Fig. 5 Interação entre as variáveis etilismo e HPV, no estádio clínico avançado (III e IV). AC Camargo Cancer Center 1984-2012

Ao analisarmos na figura 6, a associação entre as variáveis tabagismo e HPV, no estádio precoce (I e II), o paciente não tabagista apresentou uma sobrevida melhor, mas não foi estatisticamente significativo $(\mathrm{p}=0,340)$. A presença do HPV não influenciou a sobrevida global. 


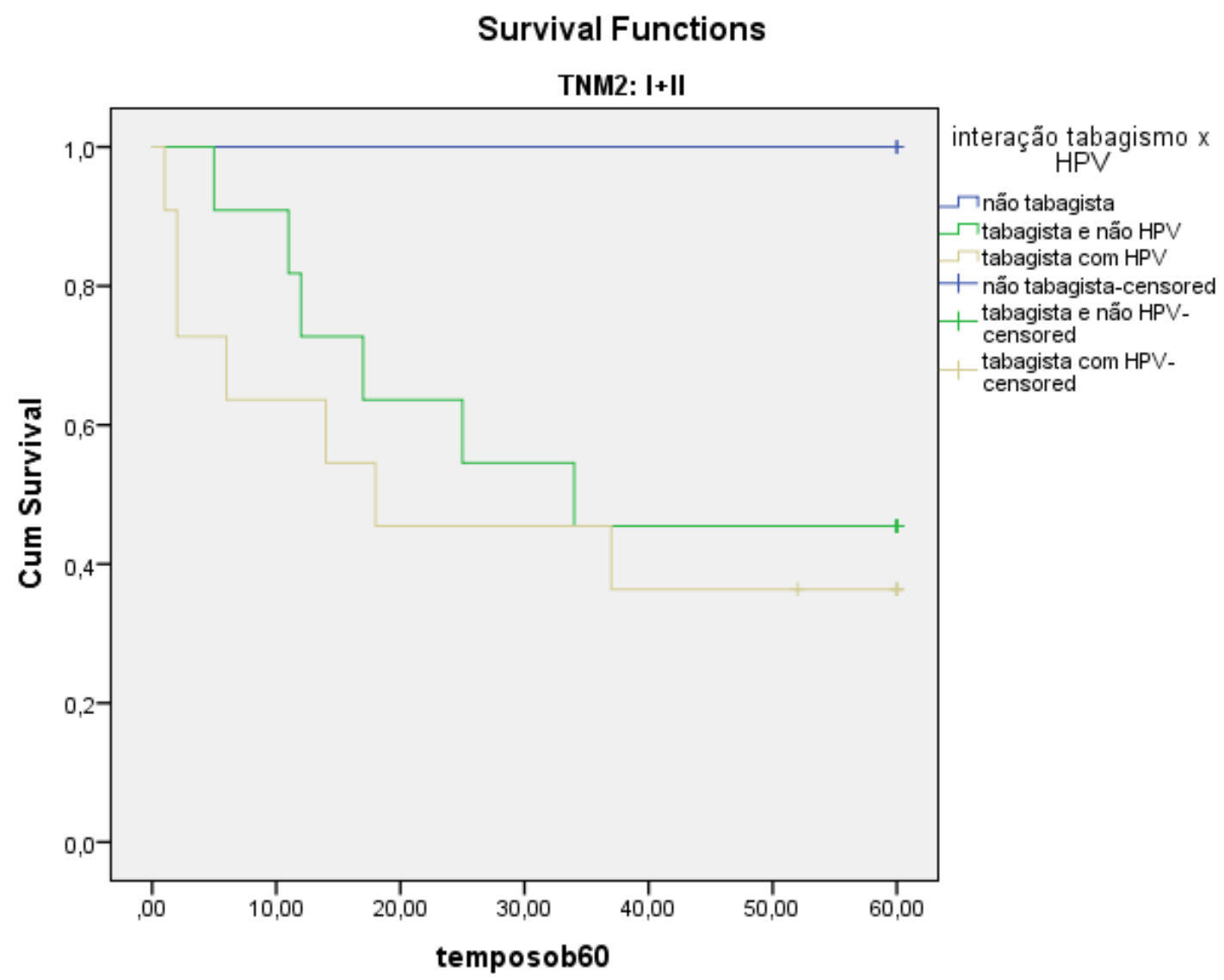

Fig. 6 Interação entre as variáveis tabagismo e HPV, no estádio precoce (I e II). AC Camargo Cancer Center 1984-2012

Na figura 7, a associação entre as variáveis tabagismo e HPV, no estádio avançado (III e IV), o paciente não tabagista não apresentou uma sobrevida melhor. O valor de $p=0,604$, não foi estatisticamente significativo. A presença do HPV também não influenciou a sobrevida global. 


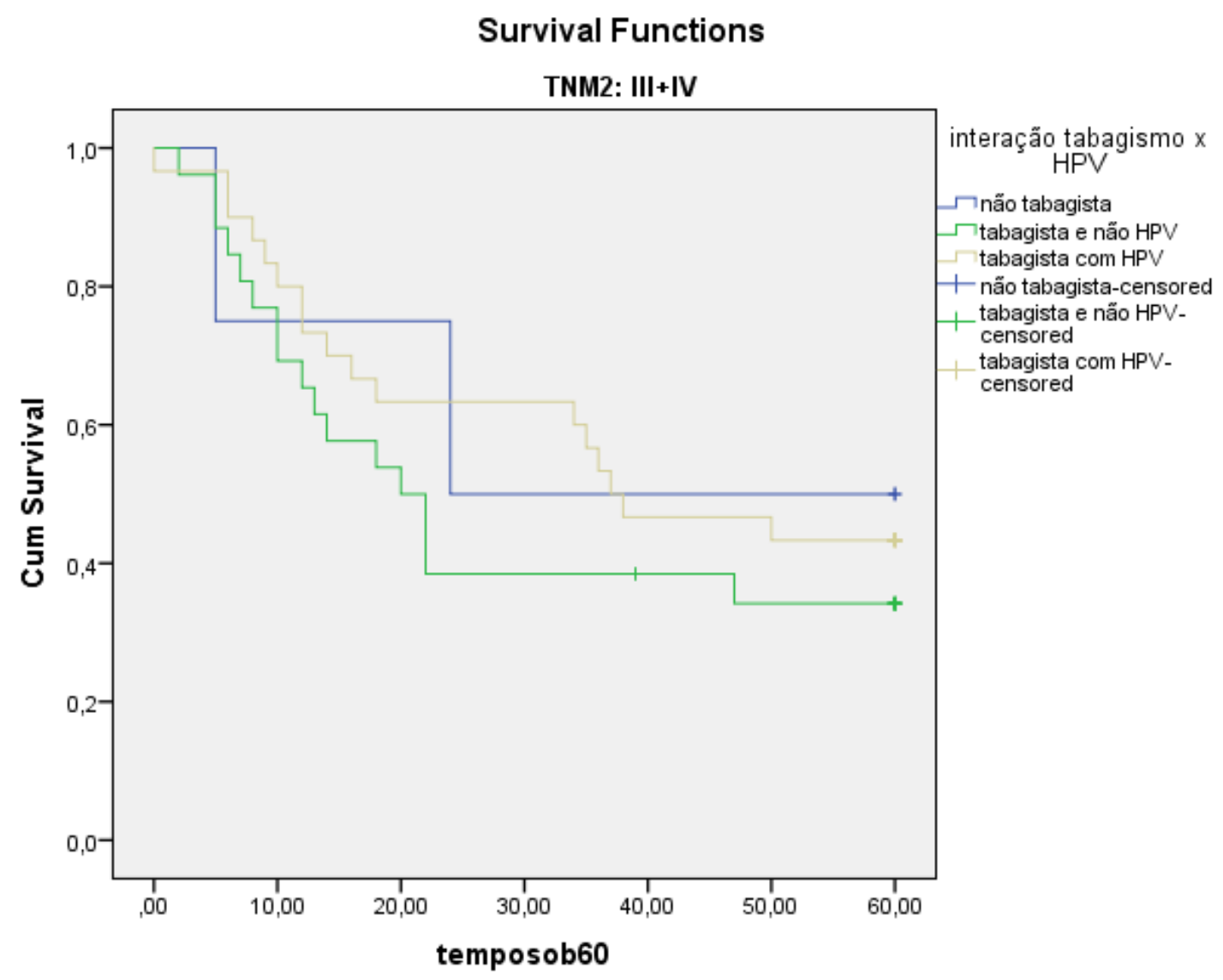

Fig. 7 Interação entre as variáveis tabagismo e HPV, no estádio avançado (III e IV). AC Camargo Cancer Center 1984-2012 


\section{DISCUSSÃo}

A associação entre o HPV e o câncer de cabeça e pescoço vem sendo demonstrada desde 1982 (Syrjänen et al, 1982), mas somente em 2007 houve um reconhecimento do seu papel oncogênico, pelo IARC. Está claro também, que o câncer de orofaringe HPV associado, é uma entidade clinica, biológica e patológica diferente do HPV não associado (Sikora et al., 2004, Gillison et al., 2004, D’Souza et al., 2010, Allen et al., 2010, Adelstein et al., 2010, Marur et al., 2010, Snow et al., 2010, Rietbergen et al., 2013, Hauck et al., 2015).

Analisamos 86 pacientes portadores de carcinoma de células escamosas de orofaringe do período de 1984 a 2012, tratados por cirurgia, quanto às características demográficas e estilo de vida, características clínicas, patológicas, cirúrgicas e presença do HPV, associada a essas características. Também estudamos nesses pacientes a análise da sobrevida livre de doença e a sobrevida global, e a interação destas com o estilo de vida, estádio clínico e HPV.

Em relação ao sexo, com predominância do masculino $(88,4 \%)$, à idade com discreta predominância da sexta década $(53,5 \%)$, à raça branca $(83,7 \%)$ os resultados apresentados são semelhantes aos apresentados na literatura (Gillison, 2004, Begum et al., 2005, Fakhry et al., 2006, D’Souza et al., 2007, Andrews et al., 2009, D’Souza et al., 2010, Ramqvist et al., 2010, Lescaille et al., 2011, Chung et al., 2013, Evans et al., 2013, Habbous et al., 2013, Bastos de Souza et al., 2013, Dalianis T, 2014a).

Quanto ao estilo de vida, o tabagismo e etilismo, a localização do tumor primário, a amígadala $(69,8 \%)$ e o estádio clínico (Begum et al., 2005, Smith et al., 2006, Ihloff et al., 2010, Maxwell et al., 2010, Blomberg et al., 2011, Psychogios et al., 2014). Este avançado, em 71,4\%, foram os estádios III e IV. As grandes cirurgias foram 
realizadas, como as bucofaringectomias $(88,4 \%)$, acompanhadas de esvaziamentos cervicais ipsilaterais $(94,2 \%)$. Também a reconstrução cirúrgica foi bem utilizada $(81,4 \%)$ e, suas complicações $(54,7 \%)$. Oitenta e seis por cento receberam radioterapia adjuvante no tumor primário e região de drenagem cervical (Hong et al., 2010, Psychogios et al., 2013).

O exame anátomo patológico não demonstrou prevalência do tipo basalóide, como na literatura (Gillison et al., 2000, Attner et al., 2010, Cooper et al., 2013), e sim do grau II, moderadamente diferenciado. As margens cirúrgicas estavam livres em $75,3 \%$, sem invasão perineural (64\%) e vascular (86\%).

A prevalência de HPV em $57 \%$ dos pacientes, e o tipo 16 em 83,6\%, estavam de acordo com dados da literatura, que varia de 14 a 82\% (Wilczynski et al., 1998, Gillison et al., 2000, Lindel et al., 2001, Begum et al., 2005, Ringström et al., 2002, Gillison et al., 2004, Smith et al., 2006, Maxwell et al., 2010, Ang et al., 2010, De Stefani et al., 2013, Hama et al., 2014, Cerezo et al., 2014). A associação do HPV com os dados demográficos e estilo de vida, só se mostrou estatisticamente significativa com o tabagismo, onde todos os não fumantes tinham HPV contra 53,8\% nos fumantes/exfumantes ( $p=0,027$ ) (Gillison et al., 2009, Maxwell et al., 2010, Ljøkjel et al, 2014). Porém se olharmos atentamente a idade, sugere-se que pacientes com idade $\geq$ de 55 anos são HPV positivos. A raça não branca estava associada ao HPV em 75\%. Ambas características não foram estatisticamente significativas. Com o estádio clínico também não houve associação com o HPV estatisticamente significativa, e também diferente de alguns estudos (Ang et al., 2010, Psychogios et al., 2013, Tahtali et al., 2013, Benson et al., 2014, Hama et al., 2014, Ljøkjel et al., 2014, Keane et al., 2015), porém de acordo com Licitra et al., 2006, que não encontrou relação com HPV positivo associado com estádio clínico. 
As características anátomo patológicas como margens cirúrgicas, grau histológico de diferenciação, embolização vascular, invasão neural e a presença de linfonodos ipsi ou contralaterais, associadas com a presença do HPV não mostrou nenhuma estatisticamente significativa. A característica que sugeriu alguma relação entre a sua presença e o HPV foi a margem cirúrgica, revelando ser importante para a sobrevida livre de doença.

A análise de sobrevida livre de doença mostrou que $43 \%$ dos pacientes apresentaram recidiva. Houve diferença estatisticamente significativa entre as curvas de sobrevida livre de doença, segundo a idade e a margem cirúrgica. Assim idade maior ou igual a 55 anos tem maior sobrevida $(80,7 \%)$ contrariando alguns dados da literatura (Ljøkjel et al., 2014) e margem negativa também (78,1\%) no primeiro, segundo $(72,6 \%)$ e com 5 anos $(66,2 \%)$ de seguimento, contra $61,0 \%$ no primeiro ano, $45,1 \%$ no segundo e $31,0 \%$ com 5 anos de seguimento para margens positivas. A presença do HPV pouco influenciou a sobrevida livre de doença, não a ponto estatisticamente significativo. No modelo múltiplo de Cox, verificou-se que a idade até 55 anos $(\mathrm{HR}=2,6 ; \mathrm{p}=0,008)$ e o comprometimento de margens $(\mathrm{HR}=2,3 ; \mathrm{p}=0,026)$, são fatores de risco independentes para a sobrevida livre de doença de pacientes com carcinoma de células escamosas de orofaringe tratados por cirurgia.

No entanto ao realizarmos algumas associações entre o HPV, o tabagismo, o etilismo, o estádio clínico, e a sobrevida livre de doença, não encontramos nenhuma delas estatisticamente significativa, diferente dos achados de Begum et al., 2003, Fakhry et al., 2006, Fakhry et al., 2008, Ang et al., 2010, Lill et al., 2011, Tahtali et al., 2013, Dahlstrom et al., 2013, Fakhry et al., 2014, Hauck et al., 2015, que encontraram nos pacientes HPV positivo portadores de carcinoma de células escamosas uma melhor sobrevida livre de doença. 
A análise de sobrevida global mostrou diferença estatisticamente significativa comparando com o etilismo. Assim o paciente não etilista tem melhores taxas de sobrevida em relação ao etilista, no primeiro ano $(75,0 \% \times 68,5 \%)$, no segundo ano $(68,8 \%$ x 46,3\%) e com cinco anos (62,5\%x 31,5\%). O HPV não influenciou a sobrevida global contrariando também alguns relatos da literatura de Begum et al., 2003, Fakhry et al., 2006, Fakhry et al., 2008, Ang et al., 2010, Lill et al., 2011, Tahtali et al., 2013, Dahlstrom et al., 2013, Fakhry et al., 2014. As piores taxas de sobrevida global foram com os etilistas. O seguimento médio foi de 35 meses. Quarenta e nove pacientes tiveram óbito até os 60 meses.

Realizamos associações entre o tabagismo, etilismo, estádio clínico e a presença de HPV, com a sobrevida global e nenhuma dessas características foi estatisticamente significativa, também diferente de Begum et al., 2003, Fakhry et al., 2006, Licitra et al., 2006, Fakhry et al., 2008, Ang et al., 2010, Lill et al., 2011, Tahtali et al., 2013, Dahlstrom et al., 2013, Bensom et al., 2014, Fakhry et al., 2014, Psychogios et al., 2014, Ljøkjel et al., 2014, Hauck et al., 2015, que encontraram dados consistentes com uma melhor sobrevida global para o paciente com HPV.

Os pacientes não fumantes e não etilistas em relação aos fumantes e etilistas, tem o melhor prognóstico, melhor sobrevida livre de doença e sobrevida global, onde o HPV não interferiu na sobrevida. 


\section{CONCLUSÕES}

7.1. A prevalência do HPV nos pacientes com carcinoma de células escamosas de orofaringe submetidos a cirurgia foi $57 \%$.

7.2. A presença do HPV não determinou melhor sobrevida livre de doença, nem sobrevida global nesses pacientes.

7.3. A presença da margem cirúrgica não comprometida e a idade maior de 55 anos foram fatores independentes determinante de melhor sobrevida livre de doença.

7.4. A presença do HPV não se mostrou importante, como fator prognóstico, nessa série cirúrgica se o paciente for etilista e ou tabagista. 


\section{Anexo A}

RGH:

Idade: _ anos

Sexo (1)masc (2)fem

Raça (1) branca (2) negra (3) amar (4)outra

Tempo de história clinica meses

Sintomas (1)odinofagia (2)fumo (3)nódulo cervical (4)emagrecimento (5)outras

Etilista (0) não (1) sim ( ) quantidade ( )tempo de consumo

Fumo (0) não (1) sim ( ) quantidade ( ) tempo de consumo

Histologia biópsia (1) CEC I (2) CEC II (3) CEC III (4) Ca indiferenciado (5) ca "in situ

Local tu (1)amígdala (2)base de língua (3)valécula (4)palato mole (5)parede post

$\mathrm{T}(1) \mathrm{T} 1(2) \mathrm{T} 2$ (3)T3 (4)T4a (5)T4b

N (0)N0 (1)N1 (2)N2a (3) N2b (4) N2c (5)N3

M (0) M0 (1)M1

Data da cirurgia

Ressecção do tu $1{ }^{\text {ario }}$ (1)endoral (2) via mandibulotomia (3) via faringotomia (4) bucofaringectomia (5) outra

Esvaziamento cerv ipsilat (0)não (1)SOH (2)ECRM (3)ECR (4)outra

Esvaziamento cerv contralat (0)não (1) SOH(2)ECRM (3)ECR (4)outra

Reconstrução (0)não (1)fechamento local (2)ret miocutaneo (3)ret microcir

Complicação (0)não (1)deiscência (2)infecção (3)fístula (4)necrose retalho (5)pneumonia (6)TVP (7) outra

Tempo internação dias

AP cirurgia grau histológico: (1) I (2) II (3) III (4)indiferenciado (5) basaloide

Margens (0)livres (1) exíguas (2) comprometidas

Invasão perineural (0)não (1) sim

Embolização vascular (0)não (1) sim 
Embolização linfática (0) não (1) sim

Linfonodos ipsi: (0) não (1) sim

Local linfonodos: + (1)I (2)II (3) III (4) IV (5) V (6)VI

No linfonodos comprometidos: (1) 1 (2) 2 (3) 3 (4) 4 (5) 5 (6) mais

Linfonodos contra: (0)não (1) sim

Local linfonodos +: (1)I (2)II (3) III (4) IV (5)V (6)VI

$\mathrm{N}^{\mathrm{o}}$ linfonodos comprometidos: (1) 1 (2)2 (3)3 (4)4 (5)5 (6) mais

Data inicio Rxt pós op:

Dose tu primário : cGy

Dose cervical : cGy

Data primeira recidiva:

Local recidiva : (0)não (1)local (2)pescoço ipsi (3)pescoço contra (4)pulmão (5)outro

Tratamento recidiva (0)RHD (1)cir (2) Rxt (3) Qt (4) sem recidiva

$2^{\circ}$ primário CID:

Data $2^{\circ}$ primário :

Tratamento $2^{\circ}$ primário (0)RHD (1) cir (2) Rxt (3) Qt (4) outro (5) sem $2^{\circ}$ prim

Outros tu CID:

Status HPV: (0) negativo (1)positivo

Status seguimento: (1) vivo sem doença (2)vivo com doença (3)Moop (4)Mo outra causa (5)Morte por câncer

Data ultima consulta de seguimento: 
Anexo B

Resultado final

\begin{tabular}{|c|c|}
\hline AMOSTRA & HPV \\
\hline $205555 \mathrm{~A}$ & NEG \\
\hline $207968 \mathrm{~A}$ & NEG \\
\hline $254611 \mathrm{D}$ & NEG \\
\hline $263135 \mathrm{~A}$ & NEG \\
\hline $277926 \mathrm{~A}$ & HPV16 \\
\hline 277926B & HPV16 \\
\hline $278067 \mathrm{~A}$ & NEG \\
\hline $278281 \mathrm{~A}$ & HPV16 \\
\hline $282318 \mathrm{~A}$ & HPV16 \\
\hline $284496 \mathrm{~A}$ & HPV16 \\
\hline $284560 \mathrm{~A}$ & HPV18, HPV26 \\
\hline $286775 \mathrm{~A}$ & HPV18 \\
\hline $288398 \mathrm{~A}$ & HPV16 \\
\hline $290281 \mathrm{~A}$ & NEG \\
\hline 290909A & NEG \\
\hline $291393 \mathrm{~A}$ & HPV26 \\
\hline $293450 \mathrm{~A}$ & NEG \\
\hline $296466 \mathrm{~A}$ & HPV16 \\
\hline $298687 \mathrm{~A}$ & NEG \\
\hline $299300 \mathrm{~A}$ & HPV16 \\
\hline $299388 \mathrm{~A}$ & NEG \\
\hline $30088 \mathrm{~A}$ & HPV16 \\
\hline $300770 \mathrm{~A}$ & NEG \\
\hline $301861 \mathrm{~A}$ & NEG \\
\hline $302723 \mathrm{~A}$ & HPV16, HPV18, HPV26 \\
\hline
\end{tabular}




\begin{tabular}{|c|c|}
\hline $302811 \mathrm{~A}$ & HPV16 \\
\hline $306029 \mathrm{~A}$ & NEG \\
\hline $310880 \mathrm{~A}$ & NEG \\
\hline $311556 \mathrm{~A}$ & HPV16 \\
\hline $311581 B$ & HPV16 \\
\hline 313973A & HPV16 \\
\hline 313839A & NEG \\
\hline $316307 \mathrm{~A}$ & HPV16 \\
\hline $316387 \mathrm{~A}$ & HPV18 \\
\hline $319162 \mathrm{~A}$ & HPV16 \\
\hline $319523 \mathrm{~A}$ & NEG \\
\hline $321157 \mathrm{~A}$ & $\overline{\mathrm{NEG}}$ \\
\hline $321453 \mathrm{~A}$ & NEG \\
\hline $321658 \mathrm{~A}$ & $\overline{\mathrm{NEG}}$ \\
\hline $322742 \mathrm{~A}$ & HPV16 \\
\hline $328217 \mathrm{~A}$ & HPV16 \\
\hline $323695 \mathrm{~A}$ & NEG \\
\hline $323696 \mathrm{~A}$ & NEG \\
\hline $325054 \mathrm{~A}$ & HPV16 \\
\hline $332169 \mathrm{~B}$ & NEG \\
\hline $335235 \mathrm{~A}$ & HPV16 \\
\hline $335811 \mathrm{~A}$ & HPV16 \\
\hline $335863 \mathrm{~A}$ & HPV16, HPV18 \\
\hline $337207 \mathrm{~A}$ & NEG \\
\hline $338334 \mathrm{~A}$ & HPV16 \\
\hline $338414 \mathrm{~A}$ & NEG \\
\hline $338582 \mathrm{~A}$ & HPV16 \\
\hline B97 000541A & HPV16 \\
\hline
\end{tabular}




\begin{tabular}{|c|c|}
\hline B97 000635 & HPV16 \\
\hline B97 001751A & HPV18 \\
\hline B97 002070A & HPV16 \\
\hline B98 002725A & NEG \\
\hline B98 003445A1 & HPV16 \\
\hline B98 007694A & NEG \\
\hline BA0 000408A & HPV16 \\
\hline BA0 001141A & HPV16 \\
\hline BA0 003857A & HPV16 \\
\hline BA0 003865A & NEG \\
\hline BA0 005519A & NEG \\
\hline BA0 006728A & HPV16 \\
\hline BA0 006883A1 & HPV45 \\
\hline BA0 010818A & NEG \\
\hline BA1 000540A1 & HPV16 \\
\hline BA1 002227A1 & HPV18 \\
\hline BA1 003290A1 & HPV16 \\
\hline BA1 004667A & NEG \\
\hline BA1 004952A & HPV16 \\
\hline BA1 007743A1 & HPV16 \\
\hline BA1 009505A1 & HPV16 \\
\hline BA1 010058A1 & HPV33 \\
\hline BA2 011493A1 & NEG \\
\hline BA4 005032A2 & HPV16 \\
\hline BA4 007136A1 & NEG \\
\hline BA5 000995A & NEG \\
\hline BA5 002220A1 & HPV16 \\
\hline BA5 006080A & HPV16 \\
\hline
\end{tabular}




\begin{tabular}{|l|l|}
\hline BA7 003121A1 & HPV16 \\
\hline 715787 & NEG \\
\hline 837991AA & HPV16 \\
\hline 916828AA & HPV16 \\
\hline 921270AA & NEG \\
\hline $1028772 \mathrm{AO}$ & NEG \\
\hline
\end{tabular}




\section{REFERÊNCIAS}

1) Adelstein D, Rodriguez CP. Human papillomavirus: changing paradigms in oropharyngeal cancer. Curr Oncol Rep. 2010;12: 115-120.

2) Allen CT, Lewis Jr JS, El-Mofty SK, Haughey BH, Nussenbaum B. Human papillomavirus and oropharynx cancer: biology, detection and clinical implications. Laryngoscope. 2010; 120: 1756-1772.

3) Almeida JR, Villanueva NL, Moskowitz AJ, Miles BA, Teng MS, Sikora A, Gupta V, Posner M, Genden EM. Preferences and utilities for health states following treatment for oropharyngeal cancer: transoral robotic surgery versus definitive (chemo)radiotherapy. Head Neck. 2014; 36 (7): 923-933.

4) Andrews E, Seaman WT, Webster-Cyriaque J. Oropharyngeal carcinoma in non-smokers and non-drinkers: a role for HPV. Oral Oncology. 2009; 45: 486491.

5) Ang KK, Harris J, Wheeler R, Weber R, Rosenthal DI, Nguyen-Tân PF, Westra WH, Chung CH, Jordan RC, Lu C, Kim H, Axelrod R, Silverman CC, Redmond KP, Gillison ML. Human papillomavirus and survival of patients with oropharyngeal cancer. N Eng J Med. 2010; 363: 24-35.

6) Attner P, Du J, Näsman A, Hammarstedt L, Ramqvist T, Lindholm J, Marklund L, Dalianis T, Munck-Wikland E. The role of Human Papillomavirus in the increased incidence of base of tongue cancer. Int J Cancer. 2010; 126: 28792884.

7) Bastos de Souza TR, Pinto CA, da Cunha Mercante AM, Nishimoto IN, Brasilino de Carvalho M, Kowalski LP. Long-term results of surgical 
treatment for advanced oropharyngeal squamous cell carcinoma. Head Neck. 2014; 36(8): 1146-54.

8) Begum S, Gillison ML, Ansari-Lari MA, Shah K, Westra WH. Detection of Human Papillomavirus in cervical lymphonodes: a highly effective strategy for localizing site of tumor origin. Clin Cancer Res. 2003; 9 (15): 6469-6475.

9) Begum S, Cao D, Gillison ML, Zahurak M, Westra WH. Tissue distribution of Human Papillomavirus 16 DNA integration in patients with tonsilar carcinoma. Clin Cancer Res. 2005; 11(16): 5694-5699.

10) Benson E, Ryan L, Eisele D, Fakhry C. The clinical impact of HPV tumor status upon head and neck squamous cell carcinomas. Oral Oncology, 2014; 50: 565574.

11) Betiol J, Villa LL, Sichero L. Impact of HPV infection on the development of head and neck cancer. Braz J Med Biol Res. 2013; 46(3): 217-226.

12) Bhatia A, Burtness B. Human papillomavirus-associated oropharyngeal cancer: defining risk groups and clinical trials. J Clin Oncol. 2015; 33(29): 3243-3250.

13) Blomberg M, Nielsen A, Munk C, Krüeger SK. Trends in head and neck incidence in Denmark, 1978-2007: focus on Human Papillomavirus associated sites. Int J Cancer. 2011; 129(3): 733-741.

14) Boscolo-Rizzo P, Del Mistro A, Bussu F, Lupato V, Baboci L, Almadori G, Da Mosto MC, Paludetti G. News insights into Human papillomavirus associated head and neck squamous cell carcinoma. Acta Otorhinlaryngol Ital. 2013; 33(2): $77-87$.

15) Bose P, Brockton N, Dort JC. Head and neck cancer: from anatomy to biology. Int J Cancer. 2013; DOI: 10.1002/ijc.28112. 
16) Boyle WF, Riggs JL, Oshiro LS, Lennete EH. Eletron microscopic identification of papova virus in laryngeal papilloma. Laryngoscope. 1973; 83: 1102-1108.

17) Brizel D. Management of Human papillomavirus induced oropharynx cancer. Proc. Am. Soc. Clin. Oncol. 2012; 1092-9118/1-10: 368-371.

18) Bussu F, Sali M, Gallus R, Vellone VG, Zannoni GF, Autorino R, Dinapoli N, Santangelo R, Martucci R, Graziani C, Miccichè F, Almadori G, Galli J, Delogu G, Sanguinetti M, Rindi G, Valentini V, Paludetti G. HPV infection in squamous cell carcinomas arising from different mucosal sites of the head and neck region. Is p16 immunohistochemistry a reliable surrogate marker? $\mathrm{Br} J$ Cancer. 2013; 108: 1157-1162.

19) Bussu F, Sali M, Gallus R, Petrone G, Zannoni GF, Autorino R, Dinapoli N, Santangelo R, Vellone VG, Graziani C, Miccichè F, Almadori G, Galli J, Delogu G, Sanguinetti M, Rindi G, Tommasino M, Valentini V, Paludetti G. HPV infection in squamous cell carcinomas arising from the oropharynx: detection of HPV DNA and p 16 immunohistochemistry as diagnostic and prognostic indicators, a pilot study. Int J Radiat Oncol Biol Phys. 2014; 89 (5): 1115-1120.

20) Campbell CMP, Kreimer AR, Lin HY, Fulp W, O’Keefe MT, Ingles DJ, Abrahamsen M, Villa LL, Lazcano-Ponce E, Giuliano AR. Long-term persistence of oral Human papillomavirus type 16: the HPV infection in men study. Cancer Prev Res. 2015; 8: 190-196.

21) Castro Junior G, Snitcovsky IML, Pasini FS. Biologia molecular dos tumores de cabeça e pescoço In Hoff, PM. Tratado de Oncologia. São Paulo, Ed. Atheneu, 2013; v.2, p.1487-1492. 
22) Cerezo L, de la Torre A, Hervás A, Ruiz A, Liñan O, López M, Villar K, Martín M. Oropharyngeal cancer related to Human papillomavirus: incidence and prognosis in Madrid, Spain. Clin Transl Oncol. 2014; 16: 301-306.

23) Chaturvedi AK, Engels EA, Pfeiffer RM, Hernandez BY, Xiao W, Kim E, Jiang B, Goodman MT, Sibug-Saber M, Cozen W, Liu L, Lynch CF, Wentzensen N, Jordan RC, Altekruse S, Anderson WF, Rosenberg PS, Gillison ML. Human papillomavirus and rising of oropharyngeal cancer incidence in the United States. J Clin Oncol. 2011; 29 (32): 4294-4301.

24) Chung $\mathrm{CH}$, Bagheri A, D’Souza G. Epidemiology of oral Human Papilloma virus infection. Oral oncol. 2013; 50 (5): 364-369.

25) Cooper T, Biron V, Adam B, Klimovicz AC, Puttagunta L, Seikaly H. Prognostic utility of basaloid differentiation in oropharyngeal cancer. $J$ Otolaryngol 2013; 42-57.

26) Dahlstrom KR, Calzada G, Hanby JD, Garden AS, Glisson BS, Li G, Roberts DB, Weber RS, Sturgis EM. An evolution in demographics, treatment and outcomes of oropharyngeal cancer at a major cancer center. Cancer. 2013; 8189.

27) Dalianis T. Human papillomavirus and oropharyngeal cancer, the epidemics and significance of additional biomarkers for prediction of response to therapy. Int $J$ Oncol. 2014a; 44: 1799-1805.

28) Dalianis T. Human papillomavirus (HPV) and oropharyngeal cancer squamous cell carcinoma. Press Med. 2014b; 43 (12): e429-e434.

29) De Stefani A, Boffano P, Averono G, Ramella A, Pia F, Bongioannini G. Prevalence and characteristics of HPV infection in oropharyngeal cancer. $J$ Craniofac Surg. 2013; 24(1) e40-e43. DOI: 10.1097/SCS.0b013e31826cfffa. 
30) Dreyer JH, Hauck F, Oliveira-Silva M, Barros MHM, Niedobitek G. Detection of HPV infection in head and neck squamous cell carcinoma: a practical proposal. Virchows Arch. 2013; 462: 381-389.

31) D’Souza G, Kreimer AR, Viscidi R, Pawlita M, Fakhri C, Koch WM, Westra WH, Gillison ML. Case control study of Human papillomavirus and oropharyngeal cancer. $N$ Engl J Med. 2007; 356: 1944-1956.

32) D’Souza G, Zhang HH, D'Souza WD, Meyer RR, Gillison ML. Moderate predictive value of demographic and behavioral characteristics for a diagnosis of HPV16 positive and HPV negative head and neck cancer. Oral Oncology. 2010; 46: $100-104$.

33) Evans M, Newcombe R, Fiander A, Powell J, Rolles M, Thavaraj S, Robinson M, Powell N. Human papillomavirus associated oropharyngeal cancer: an observational study of diagnosis, prevalence and prognosis in a UK population. BMC Cancer. 2013; 13:220.

34) Fakhry C, Gillison ML. Clinical implications of Human papillomavirus in head and neck cancers. J Clin Oncol. 2006; 24: 2606-2611.

35) Fakhry C, Westra WH, Li S, Cmelak A, Ridge JA, Pinto H, Forastiere A, Gillison ML. Improved survival of patients with Human papillomavirus positive head and neck squamous cell carcinoma in prospective clinical trial. J Natl Cancer Inst. 2008; 100: 261-269.

36) Fakhry C, Zhang Q, Nguyen-Tan PF, Rosenthal D, El-Naggar A, Garden AS, Soulieres D, Trotti A, Avizonis V, Ridge JA, Harris J, Le QT, Gillison ML. Human papillomavirus and overall survival after progression of oropharyngeal squamous cell carcinoma. J Clin Oncol. 2014; 32(30): 3365-3373. 
37) Gillison ML, Koch WM, Capone RB, Spafford M, Westra WH, Wu L, Zahurak ML, Daniel RW, Viglione M, Symer DE, Shah KV, Sidranski D. Evidence for a causal association between Human papillomavirus and a subset of head and neck cancers. J Natl Cancer Inst. 2000; 92(9): 709-720.

38) Gillison ML. Human papillomavirus associated head and neck cancer is a distinct epidemiologic, clinical and molecular entity. Semin Oncol. 2004; 31: 744-754.

39) Gillison ML. HPV and prognosis for patients with oropharynx cancer. Eur $J$ Cancer. 2009; 45 Suppl 1: 383-385.

40) Habbous S, Chu KP, Qiu X, La Delfa A, Harland LTG, Fadhel E, Hui A, PerezOrdonez B, Weinreb I, Liu FF, Waldron J, O’Sullivan B, Goldstein D, Xu W, Huang SH, Liu G. The changing incidence of Human papillomavirus associated oropharyngeal cancer using multiple imputations from 2000 to 2010 at a comprehensive centre. Cancer Epidemiol. 2013; 37: 820-829.

41) Hama T, Tokumaru Y, Fujii M, Yane K, Okami K, Kato K, Masuda M, Mineta H, Nakashima T, Sugasawa M, Sakihama N, Yoshizaki T, Hanazawa T, Kato H, Hirano S, Imanishi Y, Kuratomi Y, Otsuki N, Ota I, Sugimoto T, Suzuki S. Prevalence of HPV in oropharyngeal cancer: a multicenter study in Japan. Oncology. 2014; 87:173-182.

42) Harréus U. Malignant neoplasms of the oropharynx. In Flint, PW, Haughey BH, Lund VJ, Niparko JK, Richardson MA, Robbins KT, Thomas JR. Cummings Otolaryngology Head \& Neck Surgery. Philadelphia, Elsevier, 2010; v. 2, p. 1358-1373.

43) Hauck F, Oliveira-Silva M, Dreyer JH, Perrusi VJF, Arcuri RA, Hassan R, Bonvicino CR, Barros MHM, Niedobitek G. Prevalence of HPV infection in 
head and neck carcinomas shows geographical variability: a comparative study from Brazil and Germany. Virchows Arch. 2015; 466:685-693.

44) Hoffmann TK, Arsov A, Schirlau K, Bas M, Friebe-Hoffmann U, Klussmann JP, Scheckenbach K, Balz V, Bier H, Whiteside TL. T cells specific for HPV 16 E7 epitopes in patients with squamous cell carcinoma of oropharynx. Int $J$ Cancer. 2006; 118: 1984-1991.

45) Hong AM, Dobbins TA, Lee CS, Jones D, Harnett GB, Armstrong BK, Clark JR, Milross CG, Kim J, O’Brien CJ, Rose BR. Human papillomavirus predicts outcome in oropharyngeal cancer in patients treated primary with surgery or radiation therapy. Br J Cancer. 2010; 103: 1510-1517.

46) IARC Working Group on the evaluation of carcinogenic risks to humans. Human papillomaviruses. IARC Monogr Eval Carcinog Risks Hum. 2007; 90: 1636.

47) Ihloff AS, Petersen C, Hoffmann M, Knecht R, Tribius S. Human papillomavirus in locally advanced stage III/IV squamous cell cancer of the oropharynx and impact on choice of therapy. Oral Oncology. 2010; 46: 705-711.

48) Jo S, Juhasz A, Zhang K, Ruel C, Loera S, Wilczynski SP, Yen Y, Liu X, Ellenhorn J, Lim D, Paz B, Somlo G, Vora N, Shibata S. Human papillomavirus infection as a prognostic factor in oropharyngeal squamous cell carcinomas treated in a prospective phase II clinical trial. Anticancer Res. 2009; 29: 14671474.

49) Junqueira LC, Carneiro J. Histologia básica. $11^{\text {a }}$ ed. Rio de Janeiro: Guanabara Koogan; 2008. p. 282, 285-286, 343.

50) Keane FK, Chen YH, Neville BA, Tishler RB, Schoenfeld JD, Catalano PJ, Margalit DN. Changing prognostic significance of tumor stage and nodal stage 
in patients with squamous cell carcinoma of the oropharynx in the Human papillomavirus era. Cancer. 2015; August 1: 2594-2602.

51) Klussmann JP, Weissenborn SJ, Wieland U, Dries V, Kolligs J, Jungehuelsing M, Eckel HE, Dienes HP, Pfister HJ, Fuchs PG. Prevalence, distribution and viral load of Human papillomavirus 16 DNA in tonsillar carcinomas. Cancer. 2001; 92 (11): 2875-2884.

52) Kofler B, Laban S, Busch CJ, Lörincz B, Knecht. New strategies for HPV positives head and neck cancer. Eur Arch Otorhinolaryngol. 2014; 271: 18611867.

53) Kong SC, Narasimham B, Cao H, Kwok S, Erickson JP, Koong A, Pourmand N, Le QT. The relationship between Human papillomavirus status and other molecular prognostic markers in head and neck squamous cell carcinomas. Int $J$ Radiat Oncol Biol Phys. 2009; 74(2): 553-561.

54) Kreimer AR, Villa A, Nyitray AG, Abrahamsen M, Papenfuss M, Smith D, Hildesheim A, Villa LL, Lazcano-Ponce E, Giuliano AR. The epidemiology of oral HPV infection among a multinational sample of healthy men. Cancer Epidemiol Biomarkers Prev. 2011; 20 (1): 172-182.

55) Kreimer AR. Prospects for prevention of HPV driven oropharynx cancer. Oral Oncol. 2014; 50(6) 555-559.

56) Krupar R, Robold K, Gaag D, Spanier G, Kreutz M, Renner K, Hellerbrand C, Hofstaedter F, Bosserhoff AK. Immunologic and metabolic characteristics of HPV negative and HPV positive head and neck squamous cell carcinomas are strikingly different. Virchows Arch. 2014; 465: 299-312.

57) Kumar B, Cordell KG, Lee JS, Prince ME, Tran HH, Wolf GT, Urba SG, Worden FP, Chepeha DB, Teknos TN, Eisbruch A, Tsien CI, Taylor JMG, 
D’Silva NJ, Yang K, Kurnit DM, Bradford CR, Carey TE. Response to therapy and outcomes in oropharyngeal cancer are associated with biomarkers including Human papillomavirus, epidermal growth factor receptor, gender and smoking. Int J Radiat Oncol Biol. Phys. 2007; 69 (2): S109-S111.

58) Laskar SG, Swain M. HPV positive oropharyngeal cancer and treatment deintensification: how pertinent is it? J Cancer Res. Ther. 2015; 11(1): 6-9.

59) Lescaille G, Descroix V, Azerad J. Papillomavirus et cancers des VADS. Rev Stomatol Chir Maxillofac. 2011; 112: 160-163.

60) Lewis A, Kang R, Levine A, Maghami E. The new face of head and neck cancer: the HPV epidemic. Oncology (Willist. Park, N.Y.). 2015; 29 (9): 616626.

61) Licitra L, Perrone F, Bossi P, Suardi S, Mariani L, Artusi R, Oggioni M, Rossini C, Cantù G, Squadrelli M, Quattrone $\mathrm{P}$, Locati LD, Bergamini C, Olmi $\mathrm{P}$, Pierotti MA, Pilotti S. High risk Human Papillomavirus affects prognosis with surgically treated oropharyngeal squamous cell carcinoma. J Clin Oncol. 2006; 24 (36): 5630-5636.

62) Lill C, Kornek G, Bachtiary B, Selzer E, Schopper C, Mittlboeck M, Burian M, Wrba F, Thurnher D. - Survival of patients with HPV positive orofaringeal cancer after radiochemotherapy is significant enhanced. Wien KlinWochenschr. 2011; 123: 215-221.

63) Lindel K, Beer KT, Laissue J, Greiner RH, Aebersold DM. Human papillomavirus positive squamous cell carcinoma of the oropharynx, a radiosensitive subgroup of head and neck carcinoma. Cancer. 2001; 92 (4): 805813. 
64) Ljøkjel B, Haave H, Lybak S, Aarstad HH, Karlsdottir A, Vintermyr OK, Aarstad HJ. The impact of HPV infection, smoking history, age and operability of the patient on disease specif survival in a geographically defined cohort of patients with oropharyngeal carcinoma. Acta Oto-Laryngol. 2014; 134: 964-973.

65) Marur S, D’Souza G, Westra WH, Forastiere AA. HPV associated head and neck cancer: a virus related cancer epidemic. Lancet Oncol. 2010; 11: 781-789.

66) Masterson L, Moualed D, Liu ZW, Howard JEF, Dwivedi RC, Tysome JR, Benson R, Sterling JC, Sudhoff H, Jani P, Goon PKC. De-escalation treatment protocols for HPV associated oropharyngeal squamous cell carcinoma: a systematic review and meta-analysis of current clinical trials. Eur $J$ Cancer. 2014; 50: 2636-2648.

67) Maxwell JH, Kumar B, Feng FY. Tobacco use in Human papillomavirus positive advanced oropharynx cancer patients related to increased risk of distant metastases and tumor recurrence. Clin Cancer Res. 2010; 16: 1226-1235.

68) Miguel REV, Villa LL, Cordeiro AC, Prado JCM, Pereira Sobrinho JS, Kowalski LP. Low prevalence of Human papillomavirus in a geographic region with a high incidence of a head and neck cancer. Am J Surg. 1998; 176: 428429.

69) Mehanna H, Beech T, Nicholson T, El-Hariry I, McConkey C, Paleri V, Roberts S. Prevalence of HPV in oropharyngeal and nonoropharyngeal head and neck cancer. Systematic review and meta analysis of trends by time and region. Head Neck. 2013; 35(5): 747-755.

70) Münger K, Scheffner M, Huibregtse J, Howley PM. - Interactions of HPV E6 and E7 oncoproteins with tumour suppressor gene products. Cancer Surv. 1992; 12: $197-217$. 
71) Murray PR, Rosenthal KS, Pfaller MA. Papillomavírus e poliomavírus. In: Microbiologia Médica. $6^{\text {a }}$ ed. Rio de Janeiro, Elsevier, 2009; p. 486-491.

72) Näsman A, Nordfors C, Holzhauser S, Vlastos A, Tertipis N, Hammar U, Hammarstedt-Nordenvall L, Munck-Wikland E, Ramqvist T, Bottai M, Dalianis T. Incidence of Human papillomavirus positive tonsillar and base of tongue carcinoma: a stabilization of an epidemic of viral induced carcinoma? Eur. J. Cancer. 2015; 51: 56-61.

73) O’Sullivan B, Huang SH, Siu LL, Waldron J, Zhao H, Perez-Ordonez B, Weinreb I, Kim J, Ringash J, Bayley A, Dawson LA, Hope A, Cho J, Irish J, Gilbert R, Gullane P, Hui A, Liu FF, Chen E, Xu W. Deintensification candidate subgroups in HPV related oropharyngeal cancer according to mininal risk of distant metastasis. J Clin Oncol. 2013; 31: 543-550.

74) Panwar A, Batra R, Lydiatt WM, Ganti AK. Human papillomavirus positive oropharyngeal squamous cell carcinoma: a growing epidemic. Cancer Treat Rev. 2014; 40 (2): 215-219.

75) Pedruzzi PAG, Kowalski LP, Nishimoto,IN, Oliveira, BV, Tironi, F, Ramos, GHA. Analysis of prognostic factors in patients with oropharyngeal squamous cell carcinoma treated with radiotherapy alone or in combination with systemic chemotherapy. Arch Otolaryngol Head Neck Surg. 2008; 134: 1196-1204.

76) Perrone F, Mariani L, Pastore E, Orsenigo M, Suardi S, Marcomini B, Dariva L, Licitra L, Carbone A, Pierotti MA, Pilotti S. p53 codon 72 polymorphisms in Human papillomavirus-positive squamous cell carcinomas of the oropharynx. Cancer. 2007; 109(12): 2461-2465. 
77) Psychogios G, Mantsopoulos K, Agaimy A, Koch M, Zenk J, Waldefahrer F, Iro H. Prognostic factors in limited (T1-2, N0-1) oropharyngeal carcinoma treated with surgery + - adjuvant therapy. Head Neck. 2013; 35(12): 1752-1758.

78) Psychogios G, Alexiou C, Agaimy A, Brunner K, Koch M, Mantsopoulos K, Tomppert A, Iro H. Epidemiology and survival of HPV related tonsillar carcinoma. Cancer Med. 2014; 3 (3): 652-659.

79) Psyrri A, Rampias T, Vermorken JB. The current and future impact of Human papillomavirus on treatment of squamous cell carcinoma of the head and neck. Ann Oncol. 2014; 25: 2101-2115.

80) Quon H, Forastiere. AA. Controversies in treatment deintensification of HPV associated carcinomas: should we, how should we and whom? J Clin Oncol. 2013a; 31(5): 520-522.

81) Quon H, Cohen MA, Montone KT, Ziober AF, Wang LP, Weisntein GS, O’Malley Jr BW. Transoral robotic surgery and adjuvant therapy for oropharyngeal carcinomas and the influence of $\mathrm{p} 16^{\mathrm{ink} 4 \mathrm{a}}$ on treatment outcomes. Laryngoscope. 2013b; 123: 635-640.

82) Rampias T, Sasaki C, Psyrri A. Molecular mechamisms of HPV induced carcinogenesis in head and neck. Oral Oncology. 2014; 50 (5): 356-363.

83) Ramqvist T, Dalianis T. Oropharyngeal cancer epidemic and human papillomavirus. Emerg Infect Dis. 2010; 16(11): 1671-1677.

84) Ramqvist T, Grün N, Dalianis T. Human papillomavirus and tonsilar and base of tongue. Viruses. 2015; 7:1332-1343. Doi:10.3390/v7031332.

85) Rieckmann T, Tribius S, Grob TJ, Meyer F, Busch CJ, Petersen C, Dikomey E, Kriegs M. HNSCC cell lines positive for HPV and p16 posses higher cellular 
radiosensitivity due to an impaired DBS repair capacity. Radiother Oncol. 2013; 107(2): 242-246.

86) Rietbergen MM, Brakenholf RH, Bloemena E, Witte BI, Snijders PJF, Heideman DAM, Boon D, Koljenovic S, Baatenburg-de Jong RJ, Leemans CR. HPV detection and comorbidity: critical issues in selection of patients with oropharyngeal cancer for treatment de-escalation trials. Ann Oncol. 2013; 24: $2740-2745$.

87) Rietbergen MM, Witte BI, Velazquez ER, Snijders PJF, Bloemena E, Speel E, Brakenhoff RH, Kremer B, Lambin P, Leemans CR. Different prognostic models for different patient populations: validation of a new prognostic model for patients with oropharyngeal cancer in Western Europe. Br J Cancer. 2015; 112: $1733-1736$.

88) Ringström E, Peters E, Hasegawa M, Posner M, Liu M, Kelsey KT. Human papillomavirus type 16 and squamous cell carcinoma of the head and neck. Clin Cancer Res. 2002; 8: 3187-3192.

89) Ritchie JM, Smith EM, Summersgill KF, Hoffman HT, Wang D, Klussmann JP, Turek LP, Haugen TH. Human papillomavirus infection as a prognostic factor in carcinomas of the oral cavity and oropharynx. Int J Cancer. 2003; 104: 336-344.

90) Schache AG, Liloglou T, Risk JM, Ma X-J, Wang H, Bui S, Luo Y, Sloan P, Shaw RJ, Robinson M. Validation of a novel diagnostic standard in HPV positive oropharyngeal squamous cell carcinoma. Br J Cancer. 2013; 108: 13321339.

91) Sikora AG, Toniolo P, DeLacure MD. The changing of head and neck squamous cell carcinoma in the United States. Laryngoscope. 2004; 114:1915-1923. 
92) Skinner HD, Sturgis EM, Klopp AN, Ang KK, Rosenthal DI, Garden AS, Morrison WH, Gunn GB, Beadle BM. Clinical characteristics of patients with multiple potentially Human papillomavirus related malignancies. Head\&Neck. (wileyonlinelibrary.com) 2013; DOI 10.1002/hed.23379

93) Smith EM, Ritchie JM, Summersgill KF, Klussmann JP, Lee JH, Wang D, Haugen TH, Turek LP. Age, sexual behavior and Human papillomavirus infection in oral cavity and oropharyngeal cancers. Int. J. Cancer. 2004; 108: 766-772.

94) Smith EM, Ritchie JM, Pawlita M, Rubenstein LM, Haugen TH, Turek LP, Hamsikova E. Human papillomavirus seropositivity and risks of head and neck cancer. Int J Cancer. 2006; 120: 825-832.

95) Smith EM, Pawlita M, Rubenstein, LM, Haugen TH, Hamsikova E, Turek LP. Risk factors and survival by HPV-16 E6 and E7 antibody status in human papillomavirus positive head and neck cancer. Int J Cancer. 2009; 127: 111-117.

96) Snow AN, Laudadio J. HPV detection in head and neck squamous cell carcinomas. Adv Anat Pathol, 2010; 17: 394-403.

97) Sobin L, Gospodarowicz M, Wittekind C. TNM Classification of malignant tumours. $7^{\text {th }}$ ed. United Kigdom, Ed Wiley-Blackwell, 2009; p. 30-38.

98) Syrjänen K, Syrjänen S, Pyrhönen S. Human Papillomavirus (HPV) antigens in lesions of laryngeal squamous cell carcinomas. ORL. 1982; 44:323-334.

99) Tahtali A, Hey C, Geissler C, Filman N, Diensthuber M, Leinung M, Stöver T, Wagenblast J. HPV status and overall survival of patients with oropharyngeal squamous cell carcinoma - a retrospective study of a german head and neck cancer center. Anticancer Res. 2013; 33: 3481-3486. 
100) Tertipis N, Hammar U, Näsman A, Vlastos A, Nordfors C, Grün N, ÄhrlindRichter A, Sivars L, Haeggblom L, Marklund L, Hammarstedt-Nordenvall L, Chaturvedi AK, Munck-Wikland E, Ramqvist T, Bottai M, Dalianis T. A model for predicting clinical outcome in patients with Human pappilomavirus positive tonsillar and base of tongue cancer. Eur J Cancer. 2015; 51: 1580-1587.

101) Turner DO, Williams-Cocks SJ, Bullen R, Catmull J, Falk J, Martin D, Mauer J, Barber AE, Wang RC, Gerstenberger SL, Kingsley K. High-risk Human papillomavirus (HPV) screening and detection in health patient saliva samples: a pilot study. BMC Oral Health. 2011; 11:28.

102) Vassalo J, Pinto GA, Andrade LA. Papilloma vírus. In: Alves VAF, Bacchi CE, Vassalo J. Manual de imuno-histoquímica. São Paulo, Sociedade Brasileira de Patologia. 1999; p. 208-213.

103) Weinstein GS, Quon H, Newman J, Chalian JA, Malloy K, Lin A, Desai A, Livolsi VA, Montone KT, Cohen R, O’Malley Jr WB. Transoral robotic surgery alone for orophaaryngeal cancer. An analysis of local control. Arch Otolaryngol Head Neck Surg . 2012; 138 (7): 628-634.

104)Whang SN, Filipova M, Duerksen HP. Recent progress in therapeutics treatments and screening strategies for the prevention and treatment of HPV associated head and neck cancer. Viruses. 2015; 7: 5040-5065.

105)Wilczynski SP, Lin BT-Y, Xie Y, Paz IB. Detection of Human papillomavirus DNA and oncoprotein overexpression are associated with distinct morphological patterns of tonsillar squamous cell carcinoma. Am J Pathol. 1998; 152: 145-156. 